\title{
Regulation of zinc-dependent enzymes by metal carrier proteins
}

\author{
Michael W. Thompson
}

Received: 30 October 2021 / Accepted: 10 February 2022 / Published online: 22 February 2022

(C) The Author(s), under exclusive licence to Springer Nature B.V. 2022

\begin{abstract}
Zn}^{2+}$ ions are essential in many physiological processes, including enzyme catalysis, protein structural stabilization, and the regulation of many proteins. The affinities of proteins for $\mathrm{Zn}^{2+}$ ions span several orders of magnitude, with catalytic $\mathrm{Zn}^{2+}$ ions generally held more tightly than structural or regulatory ones. Metal carrier proteins, most of which are not specific for $\mathrm{Zn}^{2+}$, bind these ions with a broad range of affinities that overlap those of catalytic, structural, and regulatory $\mathrm{Zn}^{2+}$ ions and are thought to be responsible for distributing the metal through most cells, tissues, and fluid compartments. While little is known about how many proteins obtain or release these ions, there is now considerable experimental evidence suggesting that metal carrier proteins may be responsible for transferring metals to and from some $\mathrm{Zn}^{2+}$-dependent proteins, thus serving as a major regulatory factor for them. In this review, the biological roles of $\mathrm{Zn}^{2+}$ and structures of $\mathrm{Zn}^{2+}$ binding sites are examined, and experimental evidence demonstrating the direct participation of metal carrier proteins in enzyme regulation is discussed. Mechanisms of metal ion transfer are also offered, and the potential physiological significance of this phenomenon is explored.
\end{abstract}

M. W. Thompson $(\bowtie)$

Department of Biology, College of Arts and Sciences, Indiana State University, Terre Haute, IN 47809, USA

e-mail: michael.thompson@indstate.edu
Keywords $\mathrm{Zn}^{2+} \cdot$ Metal carrier proteins . Metallothionein · Lactoferrin · Ceruloplasmin · S100 proteins $\cdot$ Calprotectin $\cdot$ Calcyclin $\cdot$ Matrix metalloproteinase $\cdot$ Structural zinc $\cdot$ Regulatory zinc . Catalytic zinc $\cdot$ Thymosin $\cdot$ Parathymosin $\cdot \mathrm{ZnT} \cdot \mathrm{Zinc}$ chaperone $\cdot$ Metalation $\cdot$ Demetalation

$\begin{array}{ll}\text { Abbreviations } \\ \text { ZnT } & \text { Zinc transporter } \\ \text { ZIP } & \text { ZRT, IRT-like protein } \\ \text { MT } & \text { Metallothionein } \\ \text { T } & \text { Thionein } \\ \text { TFIIIA } & \text { Transcription factor IIIA } \\ \text { LTF } & \text { Lactoferrin } \\ \text { ApoLTF } & \text { Apolactoferrin } \\ \text { MMP } & \text { Matrix metalloproteinase } \\ \text { CP } & \text { Ceruloplasmin } \\ \text { CALP } & \text { Calprotectin } \\ \text { PTMA } & \text { Pro-thymosin- } \alpha \\ \text { PTMS } & \text { Parathymosin } \\ \text { PFK } & \text { Phosphofructokinase } \\ \text { aPC } & \text { Activated protein C } \\ \text { GAPDH } & \text { Glyceraldehyde-3-phosphate } \\ & \text { dehydrogenase } \\ \text { Gla } & \gamma \text {-Carboxyglutamate } \\ \text { ACE } & \text { Angiotensin-converting enzyme } \\ \text { PDLIM1 } & \text { PDS and LIM domain protein 1 } \\ \text { NET } & \text { Neutrophil extracellular trap }\end{array}$




\section{$\mathrm{Zn}^{2+}$ ions in biological systems}

Metal ions are critical to many biochemical processes and are recognized as vital micronutrients. Of these metals, zinc is by far the most commonly used in biological systems, often acting as a Lewis acid in enzyme catalysis (Bertini et al. 1985). Zinc has a full $\mathrm{d}$ shell and no ligand field stabilization energy; thus, it is chemically stable regardless of its coordination geometry. This ensures that catalytic $\mathrm{Zn}^{2+}$ ions can change geometry during catalysis to accommodate substrates and transition states as needed (Zastrow and Pecoraro 2014). $\mathrm{Zn}^{2+}$ only has one oxidation state and thus does not participate in redox reactions, making it stable in the changing chemical environments that can occur in cells during many physiological processes. Together, these properties make $\mathrm{Zn}^{2+}$ an ideal biological catalyst.

Although $\mathrm{Zn}^{2+}$ is abundant within the body, little of it is freely dissolved. Since it can compete with other metal ions for binding sites, free $\mathrm{Zn}^{2+}$ levels are kept extremely low. The experimentally determined intracellular concentration of $\mathrm{Zn}^{2+}$ is approximately $0.4 \mathrm{nM}$ (Vinkenborg et al. 2009). The free $\mathrm{Zn}^{2+}$ concentration in the extracellular compartment is also maintained at a very low level, around $0.7 \mathrm{nM}$ (Franklin et al. 2005). In plasma, free $\mathrm{Zn}^{2+}$ levels are similarly low, generally accepted to be somewhere around $0.2 \mathrm{nM}$ (Magneson et al. 1987). Most of the free $\mathrm{Zn}^{2+}$ ions are quickly removed from cells by transporters in a mechanism called zinc muffling (Colvin et al. 2010), or are buffered by sequestering them with metal carrier proteins (Krezel and Maret 2016). Because of the low concentration of free zinc, it can serve as a secondary messenger both inside of cells (Yamasaki et al. 2007) and outside of cells (Fukada and Kambe 2014) in a phenomenon known as zinc signaling. The temporary increase in $\mathrm{Zn}^{2+}$ concentration to $10^{-9} \mathrm{M}$ or above during zinc signaling can alter the functions of many proteins and enzymes (Maret 2011; Yamasaki et al. 2007).

\section{Coordination of $\mathrm{Zn}^{2+}$ ions in proteins}

Since $\mathrm{Zn}^{2+}$ is so abundant and most of it is bound to proteins, it is unsurprising that a large number of proteins in living organisms contain zinc. An estimated 3200 genes of the human genome, comprising roughly $15 \%$ of total protein-encoding genes, encode proteins that bind or are predicted to bind zinc ions (Andreini et al. 2006). These binding sites typically follow a pattern in which two of the metal-coordinating residues are 1-3 residues away in the protein's primary structure, creating a stable base, with other zinc ligands located some distance away to allow for the formation of secondary structures that provide flexibility for positioning and orienting the coordinating residues (Vallee and Auld 1990). There have been few exceptions to this pattern until recent discoveries revealed non-canonical binding sites that coordinate some regulatory and structural $\mathrm{Zn}^{2+}$ ions, redefining the current understanding of zinc coordination in proteins.

An analysis of crystallographic structures of proteins containing bound zinc ions reveals that they are typically coordinated by 4 (tetrahedral), 5 (trigonal bipyramidal), or 6 (octahedral) ligands, with 4 being the preferred coordination number. The preference for tetrahedral coordination appears to stem from the small size of the $\mathrm{Zn}^{2+}$ ion; as the number of ligands increases, repulsion forces increase and can destabilize the complex (Laitaoja et al. 2013). While little is known about the link between coordination geometry and $\mathrm{Zn}^{2+}$ affinity, there are indications that coordination geometry can influence the chemical reactivity of the ion. Mathematical modeling of the deprotonation of water by $\mathrm{Zn}^{2+}$ indicated that an octahedral coordination geometry raised the $\mathrm{pKa}$ of the reaction, suggesting that a tetrahedral coordination geometry would result in more efficient deprotonation at physiological pH levels (Bertini et al. 1990). Thus, tetrahedral geometries would be expected to predominate among $\mathrm{Zn}^{2+}$-dependent hydrolytic enzymes. Similarly, site-directed mutagenesis of a bacterial $\mathrm{Zn}^{2+}$ aminopeptidase indicated that differences in coordination geometry can influence the polarity and electrophilic nature of the $\mathrm{Zn}^{2+}$ ion during catalysis (Ataie et al. 2008). Likewise, trigonal bipyramidal and octahedral geometries introduced by metal substitutions in carbonic anhydrase were shown to cause changes in the distribution of water molecules in the active site, altering the ability of the protein to stabilize the transition state and lowering overall catalytic efficiency (Kim et al. 2020).

The most abundant zinc-coordinating amino acid residues found in proteins are cysteine (approximately 33\%), histidine (approximately 
$31 \%$ ), and aspartate or glutamate (approximately $18 \%$ ). There are also a sizable number of water molecules (about 9\%) that make up the fourth ligand of 3-residue coordination sites with tetrahedral geometries (Laitaoja et al. 2013). Although it has been difficult to establish correlations between the $\mathrm{Zn}^{2+}$ affinity of a protein and its coordination geometry or the identity of its coordinating ligands, a few trends have been noted through studies of zinc finger proteins. One study suggested that cysteine ligands increase the affinity of individual zinc fingers for their structural $\mathrm{Zn}^{2+}$ ions, as the alteration of a $\mathrm{Cys}_{2} \mathrm{His}_{2}$ zinc finger to CysAspHis or CysGluHis ${ }_{2}$ caused a 100-fold loss in affinity for the structural $\mathrm{Zn}^{2+}$ ion of the protein (Imanishi et al. 2012). Likewise, zinc fingers containing natural substitutions of glutamate or aspartate for one of the coordinating cysteine or histidine resides bound $\mathrm{Zn}^{2+}$ with a lower affinity (Kluska et al. 2018a). It was suggested that some of the observed loss in $\mathrm{Zn}^{2+}$ affinity could be explained by protein structural changes that cause the loss of normal hydrogen bonding and electrostatic interactions that would otherwise stabilize, orient, and/or polarize the coordinating residues (Kluska et al. 2018b). Although substitution of an essential cysteine or histidine residue with an acidic residue affected $\mathrm{Zn}^{2+}$ affinity, there appears to be no discernable difference in affinity between cysteine and histidine as a coordinating residue. An analysis of the $\mathrm{Zn}^{2+}$ affinities of $\mathrm{Cys}_{2} \mathrm{His}_{2}, \mathrm{Cys}_{2} \mathrm{HisCys}$, and $\mathrm{Cys}_{4}$ coordination chemistries noted no significant differences in metal affinity, although some differences in the enthalpic and entropic components of stability were observed (Rich et al. 2012). Additional analyses of zinc finger proteins reveals that the identity of the metal-coordinating ligands alone is not sufficient to predict $\mathrm{Zn}^{2+}$ affinity, and that the thermodynamic stabilization effects of surrounding amino acid residues can have a drastic effect on this affinity (Kochanczyk et al. 2015; Miloch and Krezel 2014). While there are general trends in the abundance of certain metal-coordinating residues among different classes of enzymes with catalytic $\mathrm{Zn}^{2+}$ ions (Laitaoja et al. 2013), no set guidelines that correlate these differences in affinity to the identity of the metal-coordinating residues have been established.

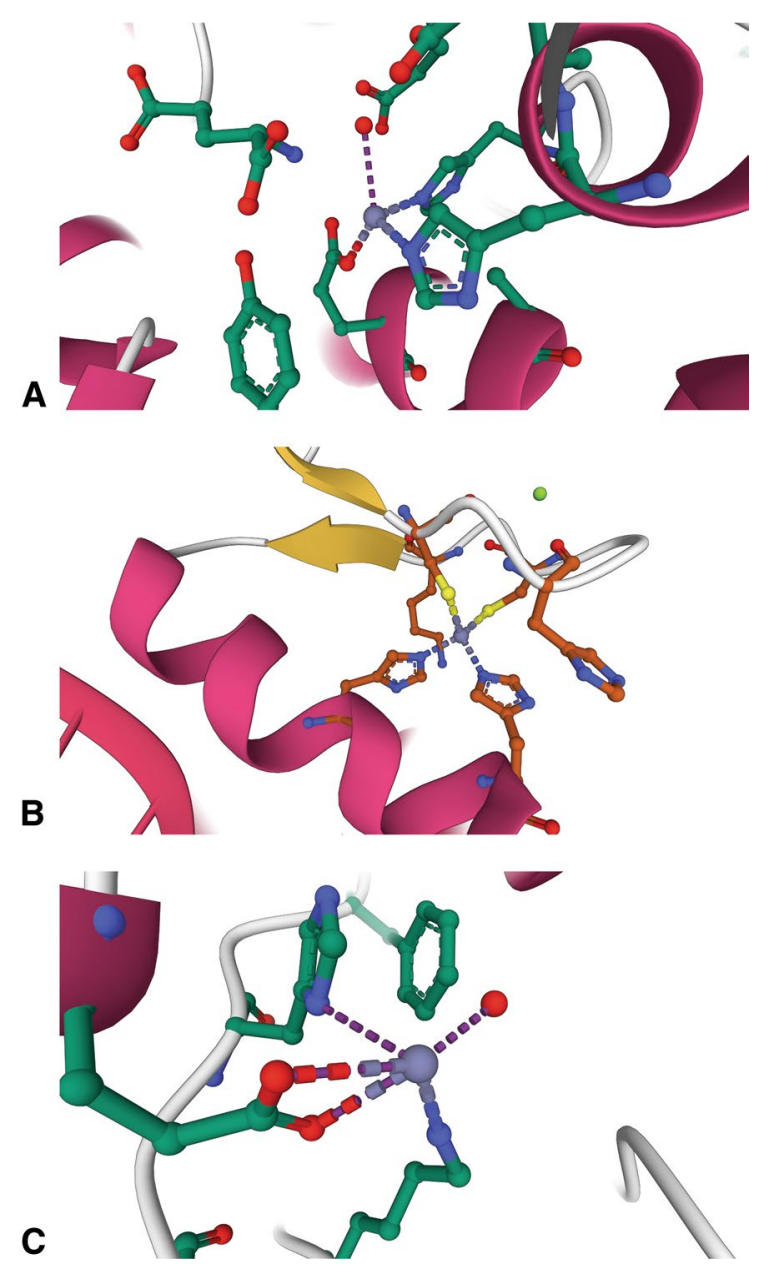

Fig. 1 The diversity of $\mathrm{Zn}^{2+}$ binding sites in protein by type. a Catalytic. Aminopeptidase A/glutamyl aminopeptidase (4KXC) contains a catalytic $\mathrm{Zn}^{2+}$ ion bound by 3 protein ligands ( 2 histidines and a glutamate residue) and a water molecule that coordinate the ion in a tetrahedral geometry (Yang et al. 2013). b Structural. The $\mathrm{Zn}^{2+}$ binding site of the $\mathrm{Cys}_{2} \mathrm{His}_{2}$ zinc finger of TFIIIA (1UN6) (Lu et al. 2003) illustrates an example of a structural $\mathrm{Zn}^{2+}$ ion. c Regulatory. Caspase- $6(4 \mathrm{FXO})$ contains a regulatory $\mathrm{Zn}^{2+}$ ion, in which the bound metal is coordinated in a distorted tetrahedral geometry through interactions with histidine, lysine, and glutamate residues. A water molecule is the fourth ligand. The glutamate is coordinated to the $\mathrm{Zn}^{2+}$ ion through a bidentate interaction (Velazquez-Delgado and Hardy 2012). Protein structure figures were created with Mol* Viewer (Sehnal et al. 2021) and RCSB PDB

\section{The roles of $\mathrm{Zn}^{2+}$ ions in proteins}

$\mathrm{Zn}^{2+}$ ions assume a variety of roles in proteins that can be characterized as catalytic, structural, or regulatory. Examples of these various types of ions are 
shown in Fig. 1. The best studied examples are catalytic $\mathrm{Zn}^{2+}$ ions, which are commonly found in hydrolytic enzymes where they are most often used to polarize and activate a water molecule to increase its nucleophilicity at physiological $\mathrm{pH}$ levels (Bertini et al. 1985). An example of this can be seen in the structure of aminopeptidase A/glutamyl aminopeptidase (Yang et al. 2013), in which the catalytic $\mathrm{Zn}^{2+}$ ion is held through interactions with two histidines and a glutamate residue; the fourth ligand is a water molecule (Fig. 1a). In most cases, the activated hydroxide is held in the correct orientation by adjacent hydrogen bonds to make it available for reaction with the substrate (Christianson and Cox 1999). Interactions of the transition state with the $\mathrm{Zn}^{2+}$ ion and nearby amino acid residues stabilize it as the geometry of the substrate changes during catalysis (Thompson et al. 2006; Thompson and Hersh 2003). The transition state is resolved and the active site regenerated by a proton shuttle that is usually mediated by a nearby histidine (Christianson and Cox 1999) or glutamate residue (Matthews 1988). Since catalytic $\mathrm{Zn}^{2+}$ ions are an integral part of these enzymatic mechanisms, most of them would be expected to be tightly bound. Experimental evidence mostly supports this, with most having $\mathrm{K}_{\mathrm{d}}$ values at the sub-nanomolar level or below (Table 1 and Fig. 2).

As more protein three-dimensional structures are being determined, many previously undetected

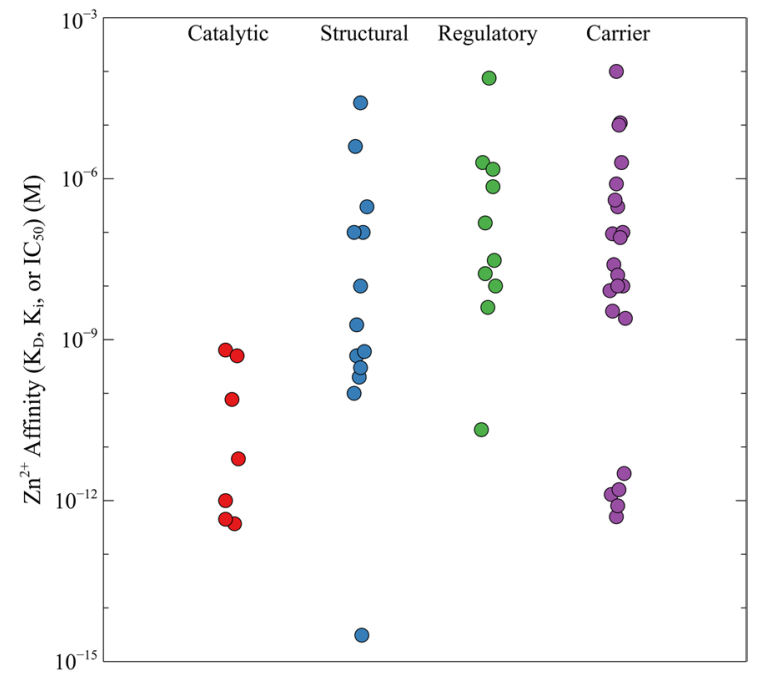

Fig. 2 Comparison of the $\mathrm{Zn}^{2+}$ binding affinities of proteins with varying types of binding sites. The experimentally determined zinc affinities $\left(\mathrm{K}_{\mathrm{d}}, \mathrm{K}_{\mathrm{i}}\right.$, or $\left.\mathrm{IC}_{50}\right)$ of catalytic, structural, regulatory, and metal carrier zinc binding sites, grouped by type

non-catalytic $\mathrm{Zn}^{2+}$ ions are being discovered. Most of these have been classified as either structural or regulatory. Structural zinc ions can be further classified as either participating in the stabilization of active site structures, transducing signals across the protein, and/or orienting active site residues (Dutta and Bahar 2010). Structural zinc ions may also facilitate
Table 1 Metal binding affinities of proteins containing catalytic $\mathrm{Zn}^{2+}$ ions

\begin{tabular}{ll}
\hline Protein & $\mathrm{K}_{\mathrm{d}}\left(\mathrm{Zn}^{2+}\right)$ \\
\hline Carbonic anhydrase & $1 \mathrm{pM}$ \\
& $(\mathrm{McC}$ Call and Fierke 2000) \\
Aminopeptidase B & $0.37 \mathrm{pM}$ \\
& $(\mathrm{Hirose}$ et al. 2006) \\
Superoxide dismutase 1 (SOD1) & $77 \mathrm{pM}$ \\
& $(\mathrm{Crow}$ et al. 1997) \\
Angiotensin-converting enzyme (ACE) & $640 \mathrm{pM}$ \\
& $($ Schullek and Wilson 1988) \\
Sorbitol dehydrogenase & $6 \mathrm{pM}$ \\
& $($ Krezel and Maret 2008) \\
Carboxypeptidase A & $0.5 \mathrm{nM}$ \\
& $($ Williams 1960) \\
Dipeptidyl peptidase III (DPP III) & $0.45 \mathrm{pM}$ \\
Glyoxalase I & $($ Fukasawa et al. 2011) \\
Matrix metalloproteinase-3 (MMP-3/stromelysin) & $27 \mathrm{pM}$ \\
& $($ Sellin and Mannervik 1984) \\
\hline
\end{tabular}


protein-protein interactions through interactions with amino acid residues near the surfaces of both interacting partners to stabilize quaternary structures (Lin et al. 2016). Structural $\mathrm{Zn}^{2+}$ ions are common in zinc finger proteins, which utilize them to stabilize the structure of the nucleic acid binding domain (Krishna et al. 2003). An example of a structural $\mathrm{Zn}^{2+}$ ion in the transcription factor TFIII is shown in Fig. 1b. The ion is coordinated to four protein ligands that hold a loop and a helix of the protein together to stabilize the tertiary structure of the protein ( $\mathrm{Lu}$ et al. 2003). Regardless of the precise role of structural $\mathrm{Zn}^{2+}$ ions in these types of proteins, their affinities are often somewhat lower than that of proteins with catalytic $\mathrm{Zn}^{2+}$ ions (Table 2 and Fig. 2).

In addition to participating in catalysis and stabilizing protein structures, $\mathrm{Zn}^{2+}$ ions can serve as a regulatory factor for many enzymes. Previously undetected regulatory $\mathrm{Zn}^{2+}$ ions are now being discovered in many proteins and enzymes, often bound to noncanonical zinc binding sites. For example, protein

Table 2 Metal binding affinities of proteins containing structural $\mathrm{Zn}^{2+}$ ions

\begin{tabular}{|c|c|}
\hline Structural $\mathrm{Zn}^{2+}$ ions & $\mathrm{K}_{\mathrm{d}}\left(\mathrm{Zn}^{2+}\right)$ \\
\hline Estrogen receptor 1 (hER- $\alpha)$ & $\begin{array}{l}0.1 \mathrm{nM}, 0.5 \mathrm{nM} \\
\text { (Payne et al. 2003) }\end{array}$ \\
\hline Glucocorticoid receptor & $\begin{array}{l}0.2 \mathrm{nM}, 0.3 \mathrm{nM} \\
\text { (Payne et al. 2003) }\end{array}$ \\
\hline PDLIM1 & $\begin{array}{l}3.1 \mathrm{fM} \\
\text { (Sikorska et al. 2012) }\end{array}$ \\
\hline Sp1 & $\begin{array}{l}600 \mathrm{pM}, 300 \mathrm{nM}, 4 \mu \mathrm{M} \\
\text { (Posewitz and Wilcox 1995) }\end{array}$ \\
\hline TFIIIA & $\begin{array}{l}100 \mathrm{nM} \\
\text { (Huang et al. 2004) } \\
10 \mathrm{nM}, 26 \mu \mathrm{M} \\
\text { (Makowski and Sunderman } \\
\text { 1992) }\end{array}$ \\
\hline p53 & $\begin{array}{l}2.1 \mathrm{nM} \\
\text { (Yu et al. 2014) }\end{array}$ \\
\hline NZF-1 & $\begin{array}{l}140 \text { pM } \\
\text { (Berkovits and Berg 1999) }\end{array}$ \\
\hline MTF-1 & $\begin{array}{l}31 \mathrm{pM} \\
\text { (Guerrerio and Berg 2004) }\end{array}$ \\
\hline Rhodopsin & $\begin{array}{l}0.1 \mu \mathrm{M} \\
\text { (Stojanovic et al. 2004) }\end{array}$ \\
\hline Suppressor of fused (SUFU) & $\begin{array}{l}1.89 \mathrm{nM} \\
\text { (Jabrani et al. 2017) }\end{array}$ \\
\hline Sonic hedgehog (SHH) & $\begin{array}{l}\leq 100 \mathrm{pM} \\
\text { (Day et al. 1999) }\end{array}$ \\
\hline
\end{tabular}

tyrosine phosphatase 1B, aldehyde dehydrogenase, glyceraldehyde 3-phosphatase, cathepsin B, and caspase-3, among others, are inhibited by $\mathrm{Zn}^{2+}$ ion concentrations in the nanomolar range (Maret 2013a). The regulatory $\mathrm{Zn}^{2+}$ ion of caspase-6 (Fig. 1c) is shown as an example. The metal is bound by 3 amino acid residues (a histidine, a glutamate, and a lysine residue) and a water molecule in a distorted tetrahedral geometry (Velazquez-Delgado and Hardy 2012).

Due to the common use of reducing agents and chelating agents in assay buffers, many regulatory $\mathrm{Zn}^{2+}$ ions have often escaped detection; thus, there are likely many more enzymes and proteins that utilize them. Although the concentration of free zinc is kept below the level at which binding of it to many of these enzymes would be significant, it is likely that the $\mathrm{Zn}^{2+}$ concentration could rise enough above this level during the transient increases in zinc concentration that have been observed during zinc signaling, making this a physiologically relevant regulatory mechanism for many proteins. As expected, regulatory $\mathrm{Zn}^{2+}$ ions are usually held with lower affinities than are structural or catalytic ones (Table 3 and Fig. 2), suggesting their lability under changing conditions.

\section{Metal carrier proteins distribute $\mathbf{Z n}^{2+}$ throughout the body and serve as regulatory factors for many $\mathrm{Zn}^{2+}$-dependent proteins and enzymes}

Although there is no consensus on what proteins are primarily responsible for distributing $\mathrm{Zn}^{2+}$, much of it appears to be trafficked throughout the body by metal carrier proteins. Most of the $\mathrm{Zn}^{2+}$ in plasma is carried by albumin or $\alpha_{2}$-macroglobulin, with a small amount associated with other proteins, like transferrin (Harris 1983). In other compartments, zinc is shuttled by metal carrier proteins such as lactoferrin, casein, transferrin, S100 proteins, metallothioneins, and ceruloplasmin (Blakeborough et al. 1983; Pabon and Lonnerdal 2000). $\mathrm{Zn}^{2+}$ binding and transport has not been identified as the primary (or sole) role of any of these carriers, and very few, if any, appear to be specific for it. Likewise, the affinities of metal carrier proteins for $\mathrm{Zn}^{2+}$ vary greatly, spanning several orders of magnitude (Fig. 2; Table 4). Some metal carrier proteins, like metallothioneins, are somewhat $\mathrm{Zn}^{2+}$-specific 
Table 3 Metal binding affinities of proteins containing regulatory $\mathrm{Zn}^{2+}$ ions

\begin{tabular}{|c|c|}
\hline Regulatory $\mathrm{Zn}^{2+}$ ions & $\mathrm{K}_{\mathrm{d}}$ or $\mathrm{IC}_{50}\left(\mathrm{Zn}^{2+}\right)$ \\
\hline Mitochondrial aconitase & $\begin{array}{l}2 \mu \mathrm{M} \\
\text { (Costello et al. 1997) }\end{array}$ \\
\hline Dimethylarginine dimethylaminohydrolase (DDAH) & $\begin{array}{l}4 \mathrm{nM} \\
\text { (Knipp et al. 2001) }\end{array}$ \\
\hline Receptor protein tyrosine phosphatase $\beta$ (PTPRB) & $\begin{array}{l}21 \mathrm{pM} \\
\text { (Wilson et al. 2012) }\end{array}$ \\
\hline Protein tyrosine phosphatase 1B (PTPN1) & $\begin{array}{l}17 \mathrm{nM} \\
\text { (Haase and Maret 2003) }\end{array}$ \\
\hline Caspase-3 & $\begin{array}{l}<10 \mathrm{nM} \\
\text { (Maret et al. 1999) }\end{array}$ \\
\hline Caspase-6 & $\begin{array}{l}150 \mathrm{nM} \\
\text { (Velazquez-Delgado and Hardy 2012) }\end{array}$ \\
\hline Caspase-9 & $\begin{array}{l}1.5 \mu \mathrm{M} \\
\text { (Huber and Hardy 2012) }\end{array}$ \\
\hline Carboxypeptidase A & $\begin{array}{l}0.71 \mu \mathrm{M} \\
\text { (Larsen and Auld 1991) }\end{array}$ \\
\hline Protein $\mathrm{C}$ & $\begin{array}{l}70-80 \mu \mathrm{M} \\
(\text { Sen et al. 2010) }\end{array}$ \\
\hline Fructose 1,6-bisphophatase & $\begin{array}{l}30 \mathrm{nM} \\
\text { (Pontremoli et al. 1978) }\end{array}$ \\
\hline Glyceraldehyde-3-phosphate dehydrogenase & $\begin{array}{l}150 \mathrm{nM} \\
\text { (Maret et al. 1999) }\end{array}$ \\
\hline $\mathrm{Ca}^{2+}$-ATPase & $\begin{array}{l}80 \mathrm{pM} \\
\text { (Hogstrand et al. 1999) }\end{array}$ \\
\hline
\end{tabular}

and exhibit very high affinities for $\mathrm{Zn}^{2+}$, with $\mathrm{K}_{\mathrm{d}}$ values in the low picomolar range. Others, such as the S100 family of proteins, have medium-high affinities for $\mathrm{Zn}^{2+}$ that are generally in the nanomolar range. Carriers that are more specific for other metal cations, such as members of the transferrin family, generally exhibit much lower affinities for $\mathrm{Zn}^{2+}$. This broad range of affinities may serve to accommodate the metalation and demetalation of proteins across the spectrum from those with very high $\mathrm{Zn}^{2+}$ affinities, such as $\mathrm{Zn}^{2+}$-dependent catalytic enzymes, to those with significantly lower $\mathrm{Zn}^{2+}$ affinities, such as proteins that contain regulatory $\mathrm{Zn}^{2+}$ ions (Table 4 and Fig. 2).

Many metal carrier proteins carry $\mathrm{Zn}^{2+}$ ions in binding sites that are located near the periphery of the protein or in an otherwise accessible location, as shown by the examples in Fig. 3. Metallothioneins are small metal carrier proteins with multiple binding sites that have widely varying affinities. Figure $3 \mathrm{a}$ shows a $\mathrm{Zn}^{2+}$ binding site in MT2 (Braun et al. 1992) that utilizes four cysteine residues; it is located near the end of a loop along the outside of the protein
(Fig. 3b). In lactoferrin, the $\mathrm{Zn}^{2+}$ ion is coordinated near the center of the protein with an octahedral geometry that utilizes a histidine, two tyrosines, an aspartate, and a bidentate interaction with a bound carbonate ion (Fig. 3c) (Jabeen et al. 2005). Although the metal is bound near the center of the protein, there is a large cleft along the surface of the protein that makes the site more accessible to solvent (Fig. 3d). The $\mathrm{Zn}^{2+}$ binding site of S100A8, shown in Fig. 3e, coordinates the ion with four histidine residues. The protein forms homodimers with two of these binding sites located at each edge of the protein, with the sites formed from two histidines contributed by each monomer (Fig. 3f) (Lin et al. 2016).

The accessibility and labile nature of $\mathrm{Zn}^{2+}$ ions bound to metal carrier proteins, in combination with their broad range of affinities, suggest that metal carrier proteins may be responsible for inserting or removing $\mathrm{Zn}^{2+}$ ions in other proteins, in turn regulating their activities. The delivery or removal of regulatory $\mathrm{Zn}^{2+}$ ions can greatly affect enzymatic activity, while the removal of catalytic and structural ones may serve as a check on the activities of some 
Table 4 Metal binding affinities of metal carrier proteins for $\mathrm{Zn}^{2+}$ ions

\begin{tabular}{|c|c|c|}
\hline Protein & Stoichiometry & $\mathrm{K}_{\mathrm{d}}\left(\mathrm{Zn}^{2+}\right)$ \\
\hline Metallothionein-1 & $\begin{array}{l}7 \\
\text { (Muñoz and Rodríguez 1995) }\end{array}$ & $\begin{array}{l}1.3 \mathrm{pM} \\
\text { (Muñoz and Rodríguez 1995) }\end{array}$ \\
\hline Metallothionein-2 & $\begin{array}{l}7 \\
\text { (Krezel and Maret 2007) }\end{array}$ & $\begin{array}{l}0.5 \mathrm{pM} \\
\text { (Jacob et al. 1998) } \\
0.8 \mathrm{pM} \\
\text { (Muñoz and Rodríguez 1995) } \\
1.6 \mathrm{pM}, 0.1 \mathrm{nM}, 20 \mathrm{nM} \\
\text { (Krezel and Maret 2007) }\end{array}$ \\
\hline Metallothionein-3 & $\begin{array}{l}7 \\
\text { (Hasler et al. 2000) }\end{array}$ & $\begin{array}{l}3.2 \mathrm{pM} \\
\text { (Hasler et al. 2000) }\end{array}$ \\
\hline Metallothionein-4 & Not reported & Not reported \\
\hline Lactoferrin & $\begin{array}{l}2 \\
\text { (Jabeen et al. 2005) }\end{array}$ & Not reported \\
\hline Ceruloplasmin & Not reported & Not reported \\
\hline S100B & Not reported & 94 nM (Wilder et al. 2003) \\
\hline S100A2 & Not reported & 25 nM (Randazzo et al. 2001) \\
\hline S100A3 & Not reported & $11 \mu \mathrm{M}$ (Fohr et al. 1995) \\
\hline S100A5 & Not reported & $2 \mu \mathrm{M}$ (Schafer et al. 2000) \\
\hline Calcyclin (S100A6) & Not reported & $100 \mathrm{nM}$ (Kordowska et al. 1998) \\
\hline Psoriasin (S100A7) & $\begin{array}{l}1 \\
\text { (Murray et al. 2012) }\end{array}$ & $\begin{array}{l}100 \mu \mathrm{M} \\
\text { (Vorum et al. 1996) } \\
1 \mathrm{nM} \\
\text { (Murray et al. 2012) }\end{array}$ \\
\hline Calprotectin (S100A8/A9) & & $\begin{array}{l}3.4 \mathrm{nM}, 8.2 \mathrm{nM} \\
\text { (Damo et al. 2013) }\end{array}$ \\
\hline S100A12 & $\begin{array}{l}2 \\
\text { (Cunden et al. 2016) }\end{array}$ & $\begin{array}{l}<10 \mathrm{nM} \\
\text { (Cunden et al. 2016; } \\
\text { Dell'Angelica et al. 1994) }\end{array}$ \\
\hline S100A15 & $\begin{array}{l}2 \\
\text { (Murray et al. 2012) }\end{array}$ & $\begin{array}{l}2.5 \mathrm{nM} \\
\text { (Murray et al. 2012) }\end{array}$ \\
\hline$\alpha_{2}$-Macroglobulin & $\begin{array}{l}16 \\
\text { (Adham et al. 1977) } \\
20 \\
\text { (Pratt and Pizzo 1984) }\end{array}$ & $\begin{array}{l}0.3 \mu \mathrm{M} \\
\text { (Adham et al. 1977) } \\
0.8 \mu \mathrm{M} \\
\text { (Pratt and Pizzo 1984) }\end{array}$ \\
\hline Albumin & $\begin{array}{l}1 \\
\text { (Ohyoshi et al. 1999) }\end{array}$ & $\begin{array}{l}80 \mathrm{nM} \\
\text { (Ohyoshi et al. 1999) }\end{array}$ \\
\hline Transferrin & $\begin{array}{l}2 \\
\text { (Harris 1983) }\end{array}$ & $\begin{array}{l}16 \mathrm{nM}, 400 \mathrm{nM} \\
\text { (Harris 1983) }\end{array}$ \\
\hline$\alpha$-fetoprotein & $\begin{array}{l}5 \\
\text { (Permyakov et al. 2002) }\end{array}$ & $\begin{array}{l}10 \mathrm{nM}, 10 \mu \mathrm{M}(\times 4) \\
\text { (Permyakov et al. 2002) }\end{array}$ \\
\hline
\end{tabular}

proteins under changing chemical conditions or regulatory proteolysis. Indeed, many studies over the past few decades have indicated that metal carrier proteins may play a significant role in regulating the activity of enzymes by supplying or removing $\mathrm{Zn}^{2+}$ ions as needed. In support of this hypothesis, some recent findings that demonstrate this type of phenomenon are reviewed, and the possible mechanisms and physiological significance of these findings are discussed.

\section{Some $\mathrm{ZnT}$ proteins can act as zinc chaperones for $\mathrm{Zn}^{2+}$-dependent enzymes}

In humans, the $14 \mathrm{ZIP}$ and $9 \mathrm{ZnT}$ proteins are responsible for the movement of $\mathrm{Zn}^{2+}$ ions in and out of cells. In general, ZIPs transport zinc into the cytoplasm of cells from the extracellular compartment and from intracellular compartments, and ZnTs move it in the opposite direction (Baltaci and Yuce 2018). 

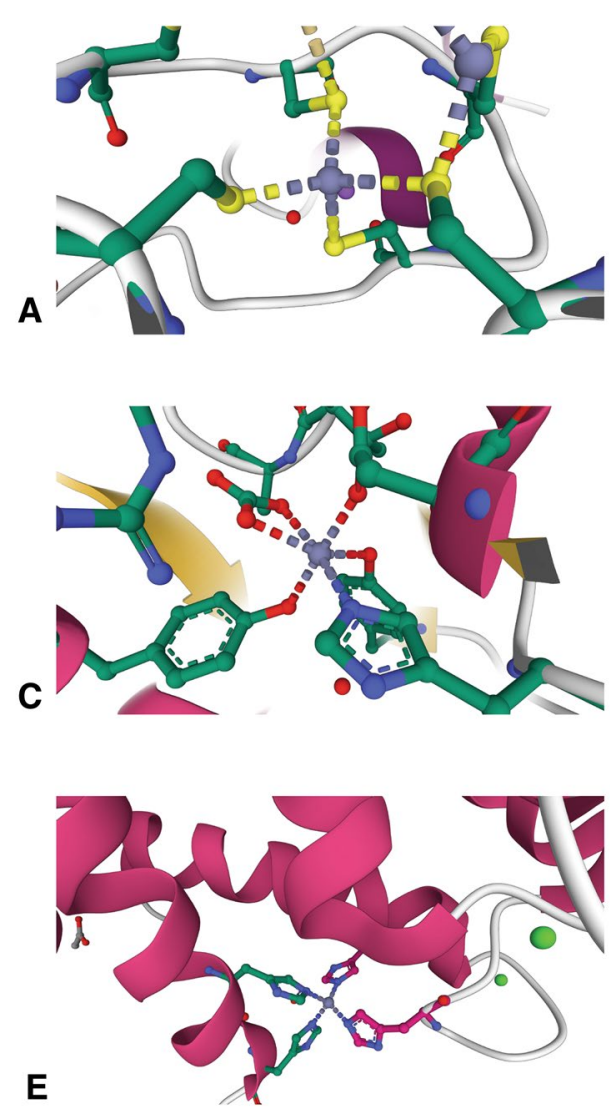

Fig. 3 Zinc binding sites in metal carrier proteins. a One of the $\mathrm{Zn}^{2+}$ binding sites in the $\beta$-domain of rat metallothionein-2 (4MT2) shows the ion coordinated in a tetrahedral geometry by four cysteine residues (Braun et al. 1992). b This $\mathrm{Zn}^{2+}$ binding site in MT2 resides in a loop near the protein's outer surface, shown near the top of the panel. c Structure of the $\mathrm{Zn}^{2+}$ binding site in the C-terminal lobe of lactoferrin (1SDX), showing an octahedral coordination geometry. There are 6 ligands, which include a histidine, two tyrosines, and an asparate residue. The remaining two ligands are contributed through a

Together, these proteins regulate the intracellular concentration of $\mathrm{Zn}^{2+}$, as well as within most cellular organelles (Kimura and Kambe 2016). These proteins are largely responsible for the control of zinc signaling in cells (Kambe 2014) and in the regulation of the intracellular $\mathrm{Zn}^{2+}$ concentration through zinc muffling (Colvin et al. 2010).

In addition to their roles in transporting zinc across membranes, some ZnT proteins have been reported to act as zinc chaperones for some enzymes. ZnT5/ZnT6 heterodimers and ZnT7 homodimers have both been demonstrated to be
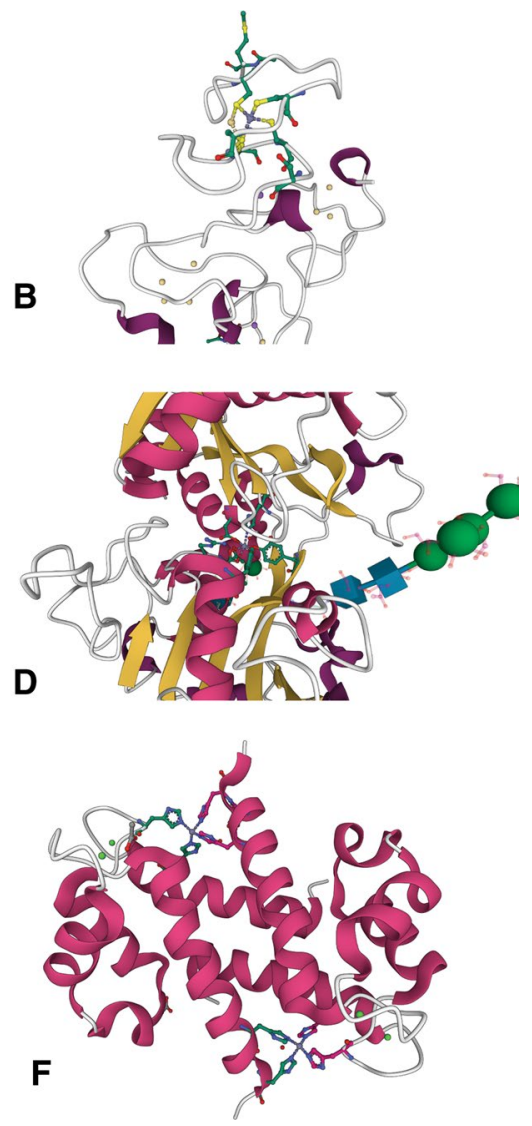

bidentate interaction with a carbonate ion (Jabeen et al. 2005). d The $\mathrm{Zn}^{2+}$ binding site of LTF is located near the center of the protein, accessible through a wide cleft. e The S100A8 homodimer (5HLV) contains two $\mathrm{Zn}^{2+}$ binding sites consisting of four histidine residues, two from each monomer, that coordinate the ion in a tetrahedral geometry (Lin et al. 2016). f The two $\mathrm{Zn}^{2+}$ binding sites of S100A8 are located on either side of the molecule at the dimer interface at the periphery of the complex. Protein structure figures were created with Mol* Viewer (Sehnal et al. 2021) and RCSB

necessary for the metalation of the apo form of tissue-nonspecific alkaline phosphatase (TNAP) in the endoplasmic reticulum. This involves a two-step mechanism involving the stabilization of the apoenzymes followed by direct zinc loading of the active site (Fujimoto et al. 2016; Fukunaka et al. 2011). Based on the phenotypes observed in cell knockout models of ZnT1, ZnT4, and metallothionein-1, it was also suggested that there are other proteins that first hand off the $\mathrm{Zn}^{2+}$ ions to ZnT5/ZnT6 and $(\mathrm{ZnT7})_{2}$ through a mechanism analogous to the copper chaperone mechanism of Atox1 (Kambe et al. 
2016), which transfers $\mathrm{Cu}^{2+}$ directly to the copper transporters ATP7A and ATP7B.

\section{Regulation of $\mathrm{Zn}^{2+}$-dependent proteins and enzymes by metallothioneins}

Metallothioneins (MTs) are a group of small intracellular sulfhydryl-containing proteins that have been implicated in the homeostasis of zinc and copper. Although they have the highest affinity for these metals, MTs are also capable of binding other metal cations, such as $\mathrm{Cd}^{2+}$, and may help sequester them to protect the cell from heavy metal poisoning (Masters et al. 1994a). These small metal-binding proteins have also been implicated in many other physiological processes, such as inflammation and immunity (Subramanian Vignesh and Deepe 2017) and in the regulation of intracellular $\mathrm{Zn}^{2+}$ levels through zinc buffering (Colvin et al. 2010).

In humans, there are eleven functional metallothioneins that fall into four groups: MT1, 2, 3, and 4 (Moleirinho et al. 2011; Si and Lang 2018). They are 61-68 residue proteins with a large number of highly conserved cysteine residues that coordinate various metal ions (Zalewska et al. 2014). MT1 and MT2 are the most ubiquitously expressed, with MT3 mostly limited to excitatory neurons in the central nervous system (Masters et al. 1994b; Palmiter et al. 1992) and MT4 limited to stratified squamous epithelia of the cutaneous membrane (Quaife et al. 1994).

Thionein (T), the apo form of metallothionein, is an intrinsically disordered protein that adopts a more defined tertiary structure consisting of two domains, $\beta$ and $\alpha$, upon binding metal ions. Four metal ions bind first to the $\mathrm{C}$-terminal $\alpha$-domain, forming a fused six-membered ring structure with the coordinating sulfhydryl groups of the protein. The N-terminal $\beta$-domain binds 3 metal ions to form a six-membered ring in a distorted chair formation. The structure of an occupied $\mathrm{Zn}^{2+}$ binding site in the $\beta$-domain of MT2 is shown in Fig. 3a, where it is coordinated with four cysteine residues (Braun et al. 1992). The high cysteine content also suggests lability of the site under changing redox conditions, which could act as a switch that makes the ion available. The binding site is located in a loop near the surface of the protein (Fig. 3b), where it is accessible to solvent or an interacting protein.
MTs have a very high affinity for zinc; however, the individual binding sites have a broad range of affinities. The four highest affinity sites exhibit $\mathrm{K}_{\mathrm{d}}$ values in the low picomolar range and would be expected to be mostly saturated at physiological intracellular $\mathrm{Zn}^{2+}$ concentrations. The other three sites, with $\mathrm{K}_{\mathrm{d}}$ values between 0.1 and $20 \mathrm{nM}$ (Krezel and Maret 2007), would likely accept or donate metal ions as needed. This supports the purported role of MTs in zinc buffering, binding or releasing of $\mathrm{Zn}^{2+}$ into the intracellular free $\mathrm{Zn}^{2+}$ pool as needed to maintain steady state levels by proxy of multiple zinc binding sites with widely different affinities (Colvin et al. 2010). The varying affinities of the $\mathrm{Zn}^{2+}$-binding sites in MTs, as well as their apparent accessibility, raises the possibility that these binding sites may interact with and regulate other metal-dependent proteins. Numerous studies indicate that this is indeed true.

In 1991, it was shown that purified T could inhibit the DNA-binding activity of the zinc finger-containing transcription factor $\mathrm{Sp} 1$, but not Oct1, which is not zinc-dependent (Zeng et al. 1991a). The reported dissociation constants of the two proteins, $600 \mathrm{pM}$ for the high-affinity binding site of Sp1 (Posewitz and Wilcox 1995) and 0.3 pM for MT1 (Muñoz and Rodríguez 1995), suggests that this interaction is likely one-way, although it is theoretically possible that MT could donate zinc ions to apo-Sp1 from one of its lower affinity binding sites. Although the T/MT ratio in most cells is quite low, it was suggested that even slight increases in $\mathrm{T}$ concentration might act as a brake on Sp1 activity (Zeng et al. 1991a). Likewise, $\mathrm{T}$ can remove zinc ions from transcription factor IIIA (TFIIIA) (Zeng et al. 1991b). The physiological significance of this interaction was established through observations of the presence of $\mathrm{T}$ in tumor cells and its direct interaction with TFIIIA. The $\mathrm{Zn}^{2+}$ transfer was hypothesized to be a second order reaction with a rate constant of $30 \mathrm{M}^{-1} \mathrm{~s}^{-1}$ and a half-time of $40 \mathrm{~min}$, which would be physiologically relevant at cellular concentrations of $\mathrm{T}$ and free $\mathrm{Zn}^{2+}$. In both cases, the donor protein is predictably the one with the lowest $\mathrm{Zn}^{2+}$ affinity, which suggests an equilibrium transfer mechanism as suggested by Huang et al. (2004) (Fig. 4a). The $\mathrm{Zn}^{2+}$ ion first dissociates from the donor protein and enters the free $\mathrm{Zn}^{2+}$ pool, immediately followed by binding of the ion by the acceptor protein. 
Fig. 4 Mechanisms of $\mathrm{Zn}^{2+}$ ion transfer between metal carriers and $\mathrm{Zn}^{2+}$-dependent enzymes. a Equilibrium transfer mechanism. The $\mathrm{Zn}^{2+}$ ion of the donor protein (green) dissociates and enters the free $\mathrm{Zn}^{2+}$ pool, followed by the binding of the free $\mathrm{Zn}^{2+}$ ion by the acceptor protein (red). b Shared ligand mechanism. Protein-protein interactions between the donor (green) and acceptor (yellow) proteins exposes binding site residues of the acceptor protein, which coordinate to the $\mathrm{Zn}^{2+}$ ion to form an intermediate in which the $\mathrm{Zn}^{2+}$ ion is shared by the two proteins. Disengagement of the protein complex causes the $\mathrm{Zn}^{2+}$ ion to remain with the acceptor protein after the proteins dissociate. $\mathbf{c}$ Altered affinities mechanism. Protein-protein interactions between the donor (green) and acceptor (red) proteins induce conformational changes that reduce the affinity of the donor protein for the $\mathrm{Zn}^{2+}$ ion and/or enhance the affinity of the acceptor. The $\mathrm{Zn}^{2+}$ ion dissociates from the donor and is then bound by the acceptor protein. Created with BioRender.com. (Color figure online)

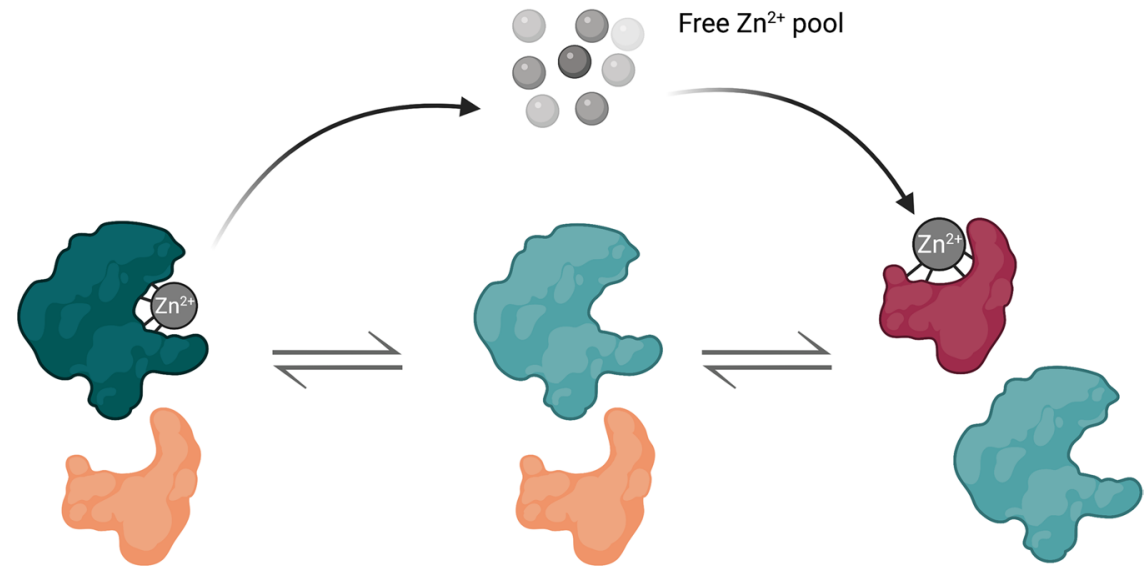

A

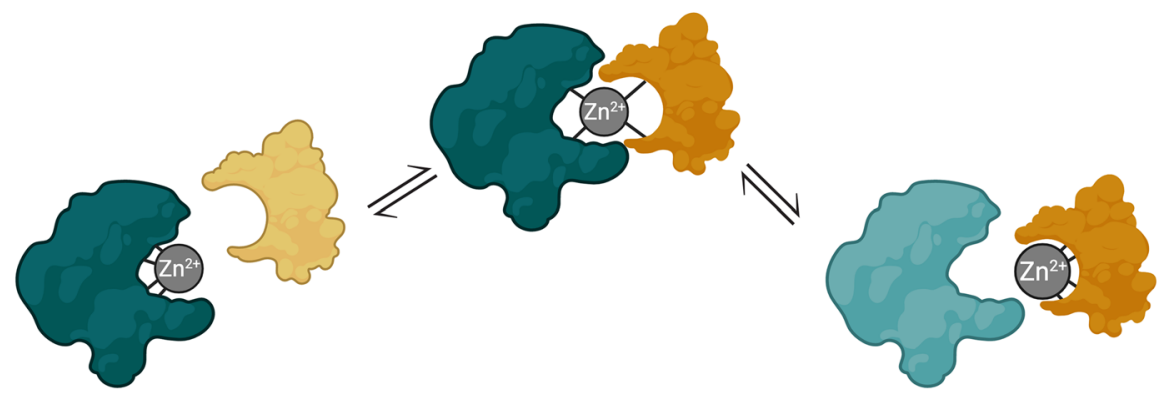

B

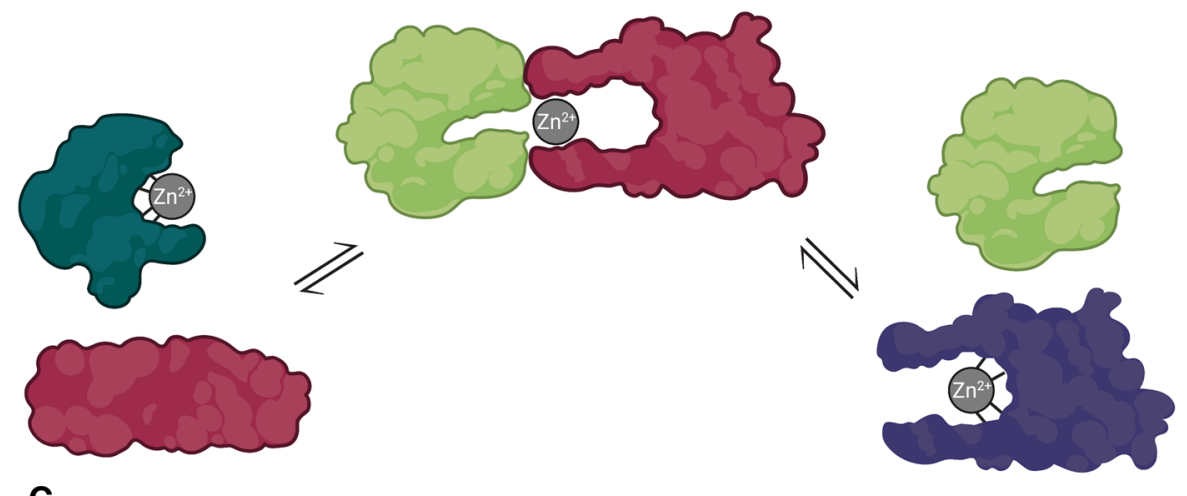

While the previous interactions appear to occur through an equilibrium transfer mechanism with $\mathrm{Zn}^{2+}$ affinity as the primary determinant of the direction of ion movement, there are some interactions of MTs with other $\mathrm{Zn}^{2+}$-dependent proteins that suggest other mechanisms are possible. For example, the movement of $\mathrm{Zn}^{2+}$ ions between T/MT and some zinc finger proteins can occur in both directions. For example,
Cano-Gauci and Sarkar (1996) demonstrated both metalation and demetalation of the estrogen receptor (ER) zinc finger by MT and T, respectively. Because a tenfold higher concentration of T/MT was required to observe metal transfer with ER versus TFIIIA, it was suggested that differences in the zinc ligands in ER $\left(\mathrm{Cys}_{4}\right.$ versus $\left.\mathrm{Cys}_{2} \mathrm{His}_{2}\right)$ or structural differences in the individual zinc fingers might explain the differences 
in kinetics. Differences in thermodynamic parameters of $\mathrm{Zn}^{2+}$ binding between $\mathrm{Cys}_{4}$ and $\mathrm{Cys}_{2} \mathrm{His}_{2}$ zinc finger binding sites (Rich et al. 2012) might be a more reasonable explanation for these observations given that there are no discernable differences in $\mathrm{Zn}^{2+}$ affinity between these two types of zinc fingers. Bidirectional transfer of $\mathrm{Zn}^{2+}$ between the $\mathrm{Cys}_{2} \mathrm{His}_{2}$ zinc finger of tramtrack (TTK) and T/MT has also been reported, although affinity of the zinc finger of TTK for $\mathrm{Zn}^{2+}$ is unknown (Roesijadi et al. 1998). In these cases, however, $\mathrm{Zn}^{2+}$ ion transfer does not always proceed from a lower affinity donor to a higher affinity acceptor, suggesting that other mechanisms, such as protein-protein interactions, may be necessary.

One possible mechanism was suggested through the characterization of interactions of $\mathrm{T}$ with the wellcharacterized tumor suppressor protein $\mathrm{p} 53$. The p53 protein, which is activated under stress conditions, contains a DNA-binding motif that is stabilized by a structural zinc ion (Meplan et al. 2000). Consistent with reports of $\mathrm{T}$ interacting with other metaldependent DNA-binding proteins, it was discovered that $\mathrm{T}$ can cause the misfolding of p53 and loss of DNA-binding activity by removing the structural $\mathrm{Zn}^{2+}$ ion from the protein's DNA-binding domain. $\mathrm{Zn}^{2+}$ removal was driven by the direct binding of sulfhydryl groups of $\mathrm{T}$ to the bound $\mathrm{Zn}^{2+}$ of $\mathrm{p} 53$ (Xia et al. 2009). Protein-protein interactions between $T$ and p53 were confirmed by co-immunoprecipitation (Ostrakhovitch et al. 2006) and surface plasmon resonance experiments (Xia et al. 2009). It was proposed that demetalation of p53 by T occurs through a shared ligand transfer model in which the $\mathrm{Zn}^{2+}$ ligands of the acceptor displace one or more of the $\mathrm{Zn}^{2+}$ ligands of the donor, followed by displacement of the remaining bonds of the donor by additional metal-binding residues of the acceptor (Fig. 4b). The idea that metal ions can bridge protein-protein interactions is not new; for example, $\mathrm{Zn}^{2+}$ can cause the dimerization of hexa-histidine ( His $_{6}$ ) affinity tags (Evers et al. 2008), and $\mathrm{His}_{6}$ affinity tags have been observed to interfere with the activity of some enzymes containing catalytic $\mathrm{Zn}^{2+}$ ions (Thompson et al. 2003). This model is also supported through direct observations of shared ligand metal transfer with other transition metals. For example, stopped-flow fluorescence experiments suggest the shared ligand transfer of $\mathrm{Cu}^{+}$ions between the E. coli CusF and CusB proteins (Chacon et al. 2018).
Interactions of MTs with proteins containing catalytic $\mathrm{Zn}^{2+}$ ions have also been observed. This was first demonstrated by the reactivation of the apo form of carbonic anhydrase $\left(\mathrm{K}_{\mathrm{d}}=1 \mathrm{pM}\right)$ by MT1 (Li et al. 1980; Udom and Brady 1980). Likewise, MT2 possesses the ability to donate $\mathrm{Zn}^{2+}$ ions to the apo form of sorbitol dehydrogenase $\left(\mathrm{K}_{\mathrm{d}}=6 \mathrm{pM}\right)$ at the T/MT ratio typically present at physiological conditions (Krezel and Maret 2008) and can activate the apo forms of MMP-9 (Zitka et al. 2011) and $\delta$-aminolevulinic acid dehydratase (Goering and Fowler 1987) as well. $\mathrm{Zn}^{2+}$ ions have also been observed moving in the opposite direction, from a donor protein with a catalytic $\mathrm{Zn}^{2+}$ ion to a thionein acceptor. $T$ possesses the ability to inhibit carboxypeptidase A, ostensibly by chelation of the active site $\mathrm{Zn}^{2+}$ ion (Jacob et al. 1998). The affinity of carboxypeptidase A for its catalytic $\mathrm{Zn}^{2+}$ ion $\left(\mathrm{K}_{\mathrm{d}}=0.5 \mathrm{nM}\right)$ (Williams 1960), is lower than most other catalytic $\mathrm{Zn}^{2+}$ ions, and is well within the ability of $\mathrm{T}$ to compete with it. $\mathrm{T}$ also demonstrated a weak ability to extract the catalytic zinc ion from alkaline phosphatase (Jacob et al. 1998). The study noted that the interaction did not proceed naturally, as predicted by thermodynamics, because of chemical buffering agents in the assay, such as citrate and glutathione, that are usually present at high concentrations in cells.

The most likely mechanism for the previous finding is the equilibrium transfer mechanism (Fig. 4a), in which $\mathrm{Zn}^{2+}$ ions are released from lower affinity binding sites of MT in response to changes in redox potential (Maret and Vallee 1998; Spahl et al. 2003; St Croix et al. 2002), making them available for subsequent protein metalation. In the interactions with carbonic anhydrase and sorbitol dehydrogenase, however, the $\mathrm{K}_{\mathrm{d}}$ of the enzyme for the catalytic $\mathrm{Zn}^{2+}$ ion is comparable to the high-affinity $\mathrm{Zn}^{2+}$ binding sites of MT (Table 4). Thus, the enzymes would not be expected to be fully metalated by this mechanism, suggesting that an alternative mechanism is likely. One such possibility is the altered affinities mechanism, in which the direct transfer of $\mathrm{Zn}^{2+}$ is facilitated through protein-protein interactions that alter the affinity of one or both proteins for the $\mathrm{Zn}^{2+}$ ion (Fig. 4c). There is also experimental support for this model. Studies of protein-protein interactions between the bacterial AztD and AztC proteins demonstrated the release of a $\mathrm{Zn}^{2+}$ ion from $\mathrm{AztD}$ and the binding of the ion by AztC. Mutagenesis of AztD 
indicated that negative cooperativity between the two metal binding sites in the protein allowed release of the ion, followed by its subsequent binding by the acceptor (Neupane et al. 2019).

Regulatory $\mathrm{Zn}^{2+}$ ions are generally held with much lower affinities than are structural and catalytic ones (Kochanczyk et al. 2015; Maret 2013b), providing a strong possibility that MTs may regulate the activity of proteins that utilize them. Since MTs generally have a higher affinity for the metal than do proteins with regulatory $\mathrm{Zn}^{2+}$ sites, the ions would be expected to move to $\mathrm{T}$ as an acceptor. This phenomenon has been observed through the ability of $\mathrm{T}$ to extract the regulatory $\mathrm{Zn}^{2+}$ ions of caspase-9 (Maret et al. 1999) and protein tyrosine phosphatase 1B (Krezel and Maret 2008), both of which exhibit a lower $\mathrm{Zn}^{2+}$ affinity than $\mathrm{T}$ (Table 3 and Table 4). Surprisingly, however, the direct transfer of $\mathrm{Zn}^{2+}$ from MT to an inhibitory regulatory binding site in aconitase has been observed (Feng et al. 2005). Since aconitase has a $\mathrm{Zn}^{2+}$ affinity that is several orders of magnitude lower than MT, the altered affinities mechanism seems a more likely method of transfer in this case.

MTs are primarily intracellular proteins; accordingly, the earlier examples of the regulation of zincdependent proteins by MTs are limited to intracellular proteins. This is consistent with the proposed role of MTs in zinc buffering of the intracellular compartment, where they not only regulate the free intracellular zinc pool, but also may add or remove metals from intracellular proteins that might not otherwise be able to obtain them from the free zinc pool. A few recent findings, however, indicating that MTs are also present within the extracellular compartment (Chung et al. 2008; Hao et al. 2007), raising the possibility that they may regulate extracellular zinc-dependent proteins as well. Observations that serum albumin binds and interacts with MTs (Atrian and Capdevila 2013) also suggests that MTs may be also involved in moving zinc ions from plasma to interstitial fluid to make them available to cells.

\section{Regulation of $\mathrm{Zn}^{2+}$-dependent enzymes by lactoferrin}

Lactoferrin (LTF) is a member of the transferrin family, which is comprised of proteins implicated in iron transport that likely arose from repeated duplications of a single ancestral iron-binding protein gene (Lambert et al. 2005). Since its discovery in 1939 as an iron binding protein and in 1960 as component of human milk (Brock 2012), it has been extensively studied and implicated primarily in the absorption and recycling of iron. Because iron is crucial for life for almost all living organisms, LTF has a well-characterized anti-microbial activity that is due to its ability to sequester iron away from microorganisms (Farnaud and Evans 2003). LTF is a major component of neutrophil granules (Furmanski and Li 1990; Wong et al. 2009) and has thus been implicated in regulating other aspects of innate immunity, including inflammation. Recent studies have indicated that LTF attenuates IL-6 production (Rosa et al. 2017), inhibits neutrophil extracellular trap (NET) formation (Okubo et al. 2016), and reduces reactive oxygen species generation (Kruzel et al. 2013), among other activities.

LTF is an extracellular glycoprotein consisting of two lobes, each containing a single metal binding site. Ferric ions are bound to each site by two tyrosine residues, one aspartate residue, and one histidine residue, and are further coordinated with the oxygen atoms of a bound carbonate anion (Baker and Baker 2004). Although LTF binds $\mathrm{Fe}^{3+}$ with highest affinity (Baker et al. 2003), it is capable of binding many other metal cations, including $\mathrm{Cu}^{2+}, \mathrm{Ce}^{4+}$, and $\mathrm{Zn}^{2+}$, with little to no change in the tertiary structure of the protein (Baker et al. 2000; Jabeen et al. 2005; Smith et al. 1992). The structure of the $\mathrm{Zn}^{2+}$-bound C-terminal lobe of LTF has been determined, showing that the ion is bound near the center of the domain in an octahedral geometry that also requires binding of a carbonate ion (Fig. 3c). Despite its location in the interior of the protein, the $\mathrm{Zn}^{2+}$ ion is largely accessible through a deep cleft that runs across the protein surface (Fig. 3d). It was also noted that the glycan bound to $\mathrm{Asn}^{545}$ lies near the entrance to the cleft and may play a role in regulating its accessibility (Jabeen et al. 2005).

Because transferrin exhibits a much lower $K_{d}$ for $\mathrm{Fe}^{2+}$ than for $\mathrm{Fe}^{3+}$ (Baker et al. 2003), it is likely that LTF exhibits a lower affinity for other divalent metal cations, such as $\mathrm{Zn}^{2+}$. Since the concentration of free $\mathrm{Zn}^{2+}$ ions in living systems is kept at a very low level relative to other metals, the role of LTF in $\mathrm{Zn}^{2+}$ homeostasis is unclear. Nevertheless, significant amounts of zinc are bound to LTF in human milk 
(Ainscough et al. 1980), and $\mathrm{Zn}^{2+}$-saturated LTF exhibits altered biochemical properties (Harrington 1992; Li et al. 2009; Marchetti et al. 1998, 1999). Thus, it is likely that zinc binding by LTF may serve an important physiological function.

In addition to its considerable roles in innate immunity, LTF has been demonstrated to interact with and regulate $\mathrm{Zn}^{2+}$-dependent proteins as well. Apolactoferrin possesses the ability to chelate the zinc ion from the active site of MMP-2, but only when the enzyme is lacking the hemopexin regulatory domain. While this interaction may be a form of extracellular zinc buffering, it is also possible that the interaction serves to regulate the activity of the enzyme once its regulatory domain has been removed as a way of attenuating its activity. It was further noted that MMP-2 inhibition by LTF was markedly increased at temperatures above $37{ }^{\circ} \mathrm{C}$ (Newsome et al. 2007), hinting that this interaction may reflect the role of LTF in innate immunity as well as enhance its zinc buffering properties under physical and chemical conditions that might cause demetalation of many metalloproteins. Although it is still unclear if the removal of the hemopexin domain of MMP-2 is a physiologically relevant step in the regulation of extracellular matrix turnover and regulation, there is some published evidence showing that this event does indeed occur under physiological conditions (Brooks et al. 1998). This would imply that the observed interaction between LTF and MMP-2 may be important. The ubiquitous expression of LTF by most glands and epithelia (Aisen and Listowsky 1980) further suggests the physiological relevance of these interactions.

Although the $\mathrm{Zn}^{2+}$ affinity of neither lactoferrin nor MMP-2 has been directly measured, it was observed in the earlier study that the form of MMP-2 lacking the hemopexin domain has a lower affinity for the catalytic $\mathrm{Zn}^{2+}$ ion than does the full-length form, which makes it more susceptible to inhibition by zinc chelation (Newsome et al. 2007). The equilibrium transfer mechanism (Fig. 4a) was suggested as the most likely mechanism; however, other mechanisms cannot be fully ruled out. The observation that the attached N-linked glycan is located near the binding cleft of the protein suggests that other mechanisms may govern the movement of metal ions into and out of LTF.

The zinc chelation activity of LTF is not limited to host enzymes, which may extend its antimicrobial activities well beyond nutritional immunity. Several recent findings indicate that LTF can also inhibit pathogen metalloproteins. For example, LTF also inhibits the $\mathrm{RgpA} / \mathrm{B}$ and Kgp proteases of Porphyromonas gingivalis, ostensibly through direct interaction of the C-terminal lobe of LTF and the zinc ion in the protease active site (Dashper et al. 2012). Likewise, LTF has also become a target of bacterial virulence factors and siderophores. For example, $\mathrm{ZmpB}$, a virulence factor of Bukholderia cenocepacia, is a zinc metalloprotease that cleaves lactoferrin, among other targets (Kooi et al. 2006). In Neisseria, the LbpAB protein is responsible for extracting iron from LTF. Since LTF exhibits a lower affinity for $\mathrm{Zn}^{2+}$, it is theoretically likely that Neisseria or other bacterial species may utilize LTF as a source for this metal as well.

\section{Regulation of $\mathrm{Zn}^{2+}$-dependent enzymes by ceruloplasmin}

Ceruloplasmin $(\mathrm{CP})$ is an abundant carrier protein in plasma that is primarily responsible for the transport of $\mathrm{Cu}^{2+}$ ions. It is encoded by a single gene, located on chromosome 3 , that gives rise to a $120 \mathrm{kDa}$ protein that is heavily glycosylated (Linder 2016). CP is the most abundant copper carrying protein found in human plasma, carrying $6 \mathrm{Cu}^{2+}$ ions (Zaitseva et al. 1996). It is also a multicopper oxidase that oxidizes substrates by transferring electrons to a bound copper ion and then to a trinuclear copper center where four electrons are then transferred to oxygen to form water (Bento et al. 2005). The primary physiological reaction catalyzed by $\mathrm{CP}$ is the oxidation of $\mathrm{Fe}^{2+}$ to $\mathrm{Fe}^{3+}$, which allows the binding of iron to transferrin (Harris et al. 1999). Structurally, the major domains of the protein are interconnected by exposed loop domains, which make the protein very susceptible to proteolysis. This susceptibility is likely linked to its physiological activity, since it has been shown that cleavage of CP by thrombin eliminates the ability of CP to inhibit myeloperoxidase (Samygina et al. 2013; Sokolov et al. 2008).

Although $>95 \%$ of serum $\mathrm{Cu}^{2+}$ is bound to $\mathrm{CP}$ (Hellman and Gitlin 2002), at least 50\% of plasma $\mathrm{CP}$ is thought to remain in the apo form (Hirano et al. 2005; Middleton and Linder 1993), suggesting the possibility that $\mathrm{CP}$ may play a role in the homeostasis of other metal ions. Although $<2 \%$ of serum CP 
contains bound $\mathrm{Zn}^{2+}$ (Lindley et al. 1997; McKee and Frieden 1971; Samygina et al. 2008), highly elevated zinc levels due to supplementation often result in copper deficiencies (Prasad et al. 1978), suggesting that $\mathrm{CP}$ may also participate in $\mathrm{Zn}^{2+}$ homeostasis under some conditions. It has also been suggested that $\mathrm{Zn}^{2+}$ may play a role in regulating the physiological function of $\mathrm{CP}$ in the rat through observations that the $\mathrm{Zn}^{2+}$-bound enzyme adopted a disordered state more characteristic of the apoenzyme (Samygina et al. 2017). This, in turn, likely affects its interactions with other proteins.

$\mathrm{CP}$ has been demonstrated to have strong antiinflammatory properties, primarily through its interactions with pro-inflammatory enzymes. In particular, $\mathrm{CP}$ has been demonstrated to form complexes with MMP-2 and MMP-12 through experiments demonstrating co-localization of the proteins in preparations of CP isolated from citrated human plasma (Sokolov et al. 2009). However, experiments to analyze gelatinolytic activity of the two MMPs in the presence of CP were not performed. The binding of the two proteins was postulated to be due to their affinity for heparin, which is seen in other proteins that form complexes with CP. There is ample evidence, however, that apoCP possesses the ability to regulate many metal-dependent enzymes, such as MMP-2 (Thompson 2012) and other enzymes with contain catalytic and regulatory $\mathrm{Zn}^{2+}$ ions (Vasilyev 2019). Likewise, $\mathrm{CP}$ has been shown to interact with LTF and the metal-containing protein myeloperoxidase, raising the possibility that it has the capability to interact with other metalloproteins as well (Sokolov et al. 2014).

Additional evidence for the regulation of zincdependent enzymes by $\mathrm{CP}$ it its reported interaction with activated protein $\mathrm{C}$ (aPC) (Walker and Fay 1990). CP bears strong homology to the aPC binding domains of factors $\mathrm{V}$ and VIII. Likewise, binding of $\mathrm{CP}$ to aPC has been demonstrated in vitro. Subsequent experiments by others have demonstrated that the interaction of aPC with endothelial cell protein $\mathrm{C}$ receptor (ECPR) is modulated by $\mathrm{Zn}^{2+}$ bound to the $\gamma$-carboxyglutamate (Gla) domain of aPC (Sen et al. 2010). Together, these results raise the possibility that CP may directly participate in the regulation of the coagulation cascade, possibly by interacting with the bound metal near the N-terminal Gla domain of aPC. In the latter study, it was noted that the apparent $\mathrm{K}_{\mathrm{d}}$ for $\mathrm{Zn}^{2+}$ binding by aPC was $\sim 70-80 \mu \mathrm{M}$, well above the plasma free $\mathrm{Zn}^{2+}$ concentration of $0.2 \mathrm{nM}$. Although the affinity of $\mathrm{CP}$ for $\mathrm{Zn}^{2+}$ has not been experimentally determined, it would suggest that the mechanism of the interaction might involve delivery of the metal to aPC by CP through a hypothetical transfer mechanism, such as the shared ligand or altered affinity mechanism (Fig. 4). The observation that $\mathrm{Zn}^{2+}$-bound rat $\mathrm{CP}$ adopts a disordered structure (Samygina et al. 2017) further suggests that the increased mobility of domains within the protein could easily interact with a target protein to facilitate metal ion transfer through one of these mechanisms.

\section{Regulation of $\mathrm{Zn}^{2+}$-dependent proteins and enzymes by members of the S100 family of proteins (calprotectin, calcyclin, and S100A12)}

S100 proteins (soluble in $100 \%$ ammonium sulfate) are a family of calcium-binding signaling proteins in vertebrates that contain a conserved EF-hand calcium-binding motif, which is shared with other calcium-binding proteins such as calmodulin and troponin-C. Currently, there are 24 known S100 proteins in humans, with the majority of them encoded by genes located in a cluster on chromosome 1q21 (Marenholz et al. 2004). Members of the S100 family contain two EF-hand calcium-binding motifs: an N-terminal EF-hand containing a 14-amino acid $\mathrm{Ca}^{2+}$-binding loop unique to $\mathrm{S} 100$ proteins, and a C-terminal EF-hand containing a 12-amino acid $\mathrm{Ca}^{2+}$-binding loop that is identical to other calciumbinding proteins (Kawasaki et al. 1998).

S100 family genes are very well conserved throughout vertebrate evolution, and it is thought that they evolved through a series of gene duplication and/ or exon shuffling events (Ravasi et al. 2004). Because S100 proteins are so well conserved, it is unsurprising that members of this family have been implicated in many physiological processes, including the regulation of cell division, inflammation, and $\mathrm{Ca}^{2+}$ homeostasis, among others. The secretion of some S100 proteins can be induced by cytokines and toll-like receptor ligands, suggesting that they may function as extracellular alarmins or damage-associated molecular patterns (DAMPs) that regulate inflammation and the innate immune response. Several S100 proteins, including S100A7 (psoriasin), S100A8/S100A9 (calprotectin), and S100A12, are also involved in 
nutritional immunity, binding $\mathrm{Zn}^{2+}, \mathrm{Cu}^{2+}$, and $\mathrm{Mn}^{2+}$ ions and limiting their availability to potential pathogens (Zackular et al. 2015). S100 proteins have also been implicated in many intracellular regulatory processes, including the regulation of apoptosis, cell differentiation, and energy metabolism (Donato et al. 2013).

Many S100 proteins are capable of binding zinc in addition to calcium (Baudier et al. 1986; Filipek et al. 1990). Cysteine-free $\mathrm{Zn}^{2+}$-binding sites were observed in the crystal structures of psoriasin (Brodersen et al. 1999), S100B (Wilder et al. 2005), and S100A8 (Lin et al. 2016). Cysteine-containing $\mathrm{Zn}^{2+}$-binding sites in S100A2 were deduced through NMR and homology modeling experiments (Randazzo et al. 2001). $\mathrm{Zn}^{2+}$ binding alters the biological activity of some members of the family, while in others it can induce dimerization. In S100A7, $\mathrm{Zn}^{2+}$ induced dimerization by creating a binding site at the dimer interface containing an $\mathrm{N}$-terminal histidine and aspartate residue from one subunit and two C-terminal histidine residues from the other subunit (Brodersen et al. 1999). Zinc can also promote dimerization of S100A8. One of two $\mathrm{Zn}^{2+}$ binding sites of a S100A8 homodimer is shown in Fig. 3e. The $\mathrm{Zn}^{2+}$ ion is coordinated by four histidine residues, two from each monomer (Lin et al. 2016). Both binding sites are located at the periphery of the protein (Fig. 3f), where they are accessible to solvent and to potential protein targets. Similar $\mathrm{Zn}^{2+}$-binding sites have been hypothesized for S100A9, S100A12, S100B (Brodersen et al. 1999), and S100A6 (calcyclin) (Maler et al. 1999). Additional low-affinity binding sites were also observed in S100A12 under conditions that caused aggregation of the protein (Moroz et al. 2009).

Zinc binding by $\mathrm{S} 100$ proteins is often linked to $\mathrm{Ca}^{2+}$ binding. In many cases, $\mathrm{Ca}^{2+}$ binding can affect the affinity of the protein for $\mathrm{Zn}^{2+}$. S100B, which can bind a total of $8 \mathrm{Zn}^{2+}$ ions, exhibits negative cooperativity between the $\mathrm{Ca}^{2+}$-binding sites and the four low-affinity $\mathrm{Zn}^{2+}$-binding sites, ostensibly due to a conformational change (Baudier et al. 1986). In contrast, no such inhibition of the $\mathrm{Zn}^{2+}$-binding sites due to $\mathrm{Ca}^{2+}$ binding was observed in calcyclin (Filipek et al. 1990) or S100A9 (Raftery et al. 1996). Despite the variety of affinities of these proteins for $\mathrm{Zn}^{2+}$ and its varied effects on their physiological functions, there is ample experimental evidence that at least some members of the S100 family are involved in the regulation of other $\mathrm{Zn}^{2+}$-dependent proteins.

The most well-characterized member of this family is calprotectin (CALP), a heterodimeric complex of S100A8 and S100A9 that forms a heterotetramer in the presence of $\mathrm{Ca}^{2+}$ (Strupat et al. 2000). Like other S100 proteins, CALP is capable of binding zinc ions at a site distinct from the protein's calcium-binding motif (Raftery et al. 1996). CALP is found in both the intracellular and extracellular compartments and participates in many different physiological processes. CALP comprises about $50-60 \%$ of the total protein present in the specific granules of neutrophils (Fagerhol et al. 1990; Johne et al. 1997), and is generally thought to mediate nutritional immunity by sequestering $\mathrm{Zn}^{2+}$ away from bacteria and other pathogens as its primary physiological function (Besold et al. 2018; Sohnle et al. 2000). Subsequent experiments have revealed that calprotectin also functions as an extracellular alarmin that activates Toll-like receptor 4 (TLR4) (Ehrchen et al. 2009; Vogl et al. 2018), and that CALP can induce apoptosis in tumor cells by withholding $\mathrm{Zn}^{2+}$ from them (Yui et al. 2002). Furthermore, CALP secretion is strongly stimulated during inflammation (Wang et al. 2018), further underscoring its role in the innate immune response.

CALP also appears to regulate many $\mathrm{Zn}^{2+}$-dependent enzymes in the extracellular compartment, much as MT does in the intracellular compartment. Most prominently, CALP may regulate the activity of many MMPs, including MMP-1, -2, -3, $-7,-8,-9$, and -13 , through a zinc chelation mechanism (Isaksen and Fagerhol 2001). The ability of calprotectin to extract the zinc ion from the various MMPs varied greatly, mostly likely due to differing $\mathrm{Zn}^{2+}$ affinities and solvent accessibility. Calprotectin inhibition was most effective against MMP-8 $\left(\mathrm{IC}_{50}=0.3 \mu \mathrm{M}\right)$ and MMP-13 $\left(\mathrm{IC}_{50}=0.5 \mu \mathrm{M}\right)$, and less effective against the gelatinases MMP-2 and -9 $\left(\mathrm{IC}_{50}=2.8 \mu \mathrm{M}\right.$ and $5 \mu \mathrm{M}$, respectively) and MMP-7 $\left(\mathrm{IC}_{50}>11 \mu \mathrm{M}\right)$. Since the plasma concentration of CALP is around $1 \mathrm{nM}$ (Cikot et al. 2016), this would not be expected to be a physiologically relevant interaction. However, very high local concentrations of CALP are present in the extracellular matrix around neutrophils upon degranulation and would likely be high enough to facilitate this reaction. It was surmised that the high concentrations of calprotectin needed to inhibit the enzymes was due to a much lower affinity 
of calprotectin for $\mathrm{Zn}^{2+}$ than MMPs. However, similarly high concentrations of LTF were needed for effective inhibition of MMP-2 (Newsome et al. 2007), suggesting that alternative mechanisms, such as the altered affinity or shared ligand mechanism, may be employed in this interaction. Thus, the high concentrations of protein needed to inhibit MMPs either reflects the high affinity of MMPs for $\mathrm{Zn}^{2+}$ ions, or their relative inaccessibility. Regardless of the reason, further evidence of the physiological significance of this interaction through the finding that overexpression of S100A8 and S100A9 in a carcinoma cell line reduced both the expression and enzymatic activity of MMP-2 (Silva et al. 2014) indicates that this event likely does occur.

Although there are no examples of direct $\mathrm{Zn}^{2+}$ chelation reactions between CALP and host regulatory $\mathrm{Zn}^{2+}$ ions, it is expected that such interactions would likely exist due to the higher $\mathrm{Zn}^{2+}$ affinity of CALP relative to the more loosely bound regulatory $\mathrm{Zn}^{2+}$ ions. There are data that highly suggest such interactions. One example is the observation that disruption of intracellular CALP in cultures of head and neck squamous cell carcinomas (HNSCC cells) caused a concomitant reduction in caspase- 3 and 7 mediated EGFR cleavage, explaining why patients with tumors expressing higher levels of CALP had better clinical outcomes (Argyris et al. 2019).

Due to its role in nutritional immunity through its ability to sequester $\mathrm{Zn}^{2+}$, CALP has become a target for zinc piracy by certain bacterial species much as LTF has. The TdfH protein of Neisseria gonorrhoeae binds to and extracts a zinc ion from human calprotectin (Kammerman et al. 2020; Stork et al. 2013) or the closely related psoriasin/S100A7 (Maurakis et al. 2019). Likewise, Salmonella typhimurium employs a similar strategy, using the zinc transporter ZnuABC to sequester $\mathrm{Zn}^{2+}$ away from CALP (Liu et al. 2012).

Other S100 family proteins have been shown to regulate $\mathrm{Zn}^{2+}$-dependent enzymes as well. S100A12, also known as calgranulin-C and EN-RAGE, is an inflammation-associated zinc and calcium-binding protein that comprises around 5\% of the total protein in neutrophils (Guignard et al. 1996) and can be found in both extracellular and intracellular forms (Donato et al. 2013). Links between S100A12 and many pathologies, including some gastrointestinal disorders and type II diabetes, have been established (Foell et al. 2003; Kosaki et al. 2004). Like the closely related S100A8 and S100A9 proteins, S100A12 also inhibits MMP-2, MMP-3, and MMP-9 with submicromolar inhibition constants, making it an even more likely regulatory factor for these enzymes than CALP, LTF, or CP. Reintroduction of zinc reversed this inhibition, emphasizing that zinc chelation by S100A12 was the most likely mechanism. These interactions were implicated in the development of atherosclerotic lesions through co-localization in foam cells (Goyette et al. 2009), suggesting that these interactions may contribute to the pathophysiology of heart disease.

An interaction between calcyclin, also known as S100A6, with melusin, a cytoplasmic chaperone protein with a $\mathrm{Zn}^{2+}$-dependent protein-protein interaction domain, has also been reported (Tsoporis et al. 2017). Although there is no direct experimental evidence of $\mathrm{Zn}^{2+}$ ion transfer between calcyclin and melusin, it is likely considering other experimental evidence. Similar interactions between melusin and S100A1 and S100A4 proteins have also been observed through co-immunoprecipitation experiments (Filipek et al. 2008), further supporting a role for $\mathrm{S} 100$ proteins in the regulation of $\mathrm{Zn}^{2+}$-dependent enzymes.

\section{Regulation of enzymes involved in carbohydrate metabolism by parathymosin}

Thymosins are a family of small zinc-binding proteins originally isolated from bovine thymus, but are also found in most other tissues. The most prominent members of the family are prothymosin- $\alpha$ (PTMA) and parathymosin (PTMS), which are encoded by separate 5-exon genes. Like MTs, thymosins are intrinsically disordered proteins that adopt a distinct tertiary structure when bound to zinc (Hannappel and Huff 2003). PTMS was identified as an inhibitor of phosphofructokinase (PFK) in the presence of $\mathrm{Zn}^{2+}$, but not in its absence (Trompeter et al. 1989), suggesting the possibility that this protein might transfer inhibitory zinc ions to PFK. While there are multiple reports of $\mathrm{Zn}^{2+}$ ions inhibiting $\mathrm{PFK}$ with $\mathrm{IC}_{50}$ values around $1 \mu \mathrm{M}$ (Brand and Soling 1986; Ikeda et al. 1980), there have been no direct reports of inhibitory zinc ions in crystal structures of PFK, nor have there been reports of the direct transfer of zinc ions from PTMS to PFK. 
PTMS was also able to bind other enzymes involved in carbohydrate metabolism, including fructose-1,6-bisphosphatase, aldolase, and glyceraldehyde-3-phosphate dehydrogenase (GAPDH), among others (Brand and Heinickel 1991). Some of these enzymes, such as GAPDH, also interact with T (Maret et al. 1999). The high concentrations of $\mathrm{Zn}^{2+}$ necessary to show inhibition in these cases, however, is well above the free zinc concentration in the intracellular compartment, making its physiological relevance questionable. Given their similarity to MTs, however, the possibility remains that PTMS and other thymosins may possess similar regulatory activities, perhaps through direct transfer of the ion to PFK via the altered affinities or shared ligand mechanism (Fig. 4). PTMS is found both in the intracellular and extracellular compartments. However, it also contains a nuclear localization signal and has been experimentally identified within the nucleus (Yu et al. 2020), suggesting that it could potentially regulate other zinc-dependent enzymes there, such as zinc finger proteins.

\section{Mechanisms of metal ion transfer between $\mathrm{Zn}^{2+}$-dependent proteins and metal carrier proteins}

Until recently, there have been few attempts to examine the mechanisms behind metal transfer reactions between proteins, but a number of clever experiments have suggested three models to explain the phenomenon. The mechanism with the most experimental evidence is the equilibrium transfer mechanism (Fig. 4A), in which the bound $\mathrm{Zn}^{2+}$ ion dissociates from the donor protein, enters the free $\mathrm{Zn}^{2+}$ pool, and is then bound by the acceptor protein. In this mechanism, the movement of the ion appears to be dependent upon the affinities of the proteins for it. In such a mechanism, however, the acceptor protein would likely compete with other metal-binding proteins in the immediate vicinity for the ion. This process, called zinc buffering, not only serves to keep the concentration of free $\mathrm{Zn}^{2+}$ ions very low, but also may be important for ensuring that metal ions are only transferred to certain acceptor proteins in order to prevent them from inappropriately binding to other regulatory sites. This also brings into question the physiological relevance of some of these reactions. In these cases, in vivo experiments utilizing ${ }^{65} \mathrm{Zn}$ or other tracers may be helpful in answering these questions.

In some instances, the regulation of zinc-dependent and zinc-regulated enzymes is much more complex. In fact, there are a few examples in which $\mathrm{Zn}^{2+}$ ions are transferred from a higher affinity donor to a lower affinity acceptor. Furthermore, structural analyses of many metal-binding sites in proteins indicate that most of them have limited solvent exposure and/or occur at or near hinge sites in proteins (Dutta and Bahar 2010). This indicates that many enzymes may require conformational changes or protein-protein interactions that increase or decrease metal affinity in order to bind or release $\mathrm{Zn}^{2+}$ ions. There are two additional mechanisms that could explain this behavior, both of which have supporting experimental evidence. One possibility is the altered affinities mechanism (Fig. 4c) in which the donor and acceptor proteins bind and undergo conformational changes that alter the affinity of one or both proteins for the metal ion, as suggested by studies of the bacterial AztC and D proteins (Neupane et al. 2019) and other instances in which $\mathrm{Zn}^{2+}$ ions are transferred from a higher affinity donor to a lower affinity acceptor. Another plausible explanation is the shared ligand mechanism (Fig. 4b), where the metal is transferred from donor to acceptor through a 2-step process in which the two proteins bind each other and undergo conformational changes that directly expose the metal ion to one or more of the ligands of the metal binding site on the acceptor protein. This interaction forms an intermediate in which the two proteins are bridged by the shared metal ion, followed by dissociation of the proteins with the metal fully bound to the acceptor protein. This hypothesis is supported by experimental evidence demonstrating interprotein contact between MT2 and the apo form of a zinc finger peptide in which a $\mathrm{Zn}^{2+}$ ion is bound to metal-coordinating residues distributed between the two interacting proteins (Hathout et al. 2001). This mechanism was also proposed to explain interactions between some bacterial metal chaperones and their corresponding acceptor proteins (Chacon et al. 2018; Neupane et al. 2019).

\section{Metal carrier proteins as regulatory factors for $\mathrm{Zn}^{2+}$-dependent proteins and enzymes}

Free $\mathrm{Zn}^{2+}$ is maintained at very low levels in the body through a combination of zinc muffling and the 
use of metal carrier proteins to distribute $\mathrm{Zn}^{2+}$ ions. This low concentration makes it theoretically difficult for proteins with low $\mathrm{Zn}^{2+}$ affinities to obtain these ions. It has been estimated that about $1 / 3$ of metalloproteins are metalated by so-called metal chaperones, while the rest draw these ions from intracellular metal pools (Foster et al. 2014). As would be expected, enzymes with catalytic zinc ions tend to have the highest affinities for them, with $K_{d}$ values of $10^{-11} \mathrm{M}$ or lower (Maret 2004), well below the free $\mathrm{Zn}^{2+}$ concentration. Thus, these proteins would be expected to be fully metalated at physiological $\mathrm{Zn}^{2+}$ concentrations and would likely obtain these ions from the intracellular free $\mathrm{Zn}^{2+}$ pool. However, there appear to be few examples of proteins that can directly draw $\mathrm{Zn}^{2+}$ ions from the intracellular pool of free metals, suggesting that a larger share of metalloproteins may obtain these metals from other proteins. A few enzymes, such as angiotensin-converting enzyme (ACE) and carboxypeptidase A, have lower affinities for $\mathrm{Zn}^{2+}$; their $\mathrm{K}_{\mathrm{d}}$ values are in the range of the free intracellular $\mathrm{Zn}^{2+}$ concentration (Table 1) and they might not be fully saturated at physiological zinc concentrations. Thus, these enzymes likely have some other means of obtaining these ions from another protein, such as a zinc chaperone or metal carrier protein. There are multiple examples of metallothioneins acting as zinc chaperones, usually through the equilibrium transfer mechanism from one of the lower affinity binding sites. Thus, it is likely that other metal carrier proteins with lower $\mathrm{Zn}^{2+}$ affinities may have the ability to act in a similar capacity.

Additional evidence that metal carrier proteins may be important regulators of zinc-dependent proteins comes from their interactions with proteins containing structural or regulatory $\mathrm{Zn}^{2+}$ ions. The $\mathrm{K}_{\mathrm{d}}$ values of these proteins for these types of $\mathrm{Zn}^{2+}$ ions are often well above the free $\mathrm{Zn}^{2+}$ concentration (Tables 2 and 3), making it unlikely that they would be able to compete for these ions from the free intracellular zinc pool. Likewise, the affinity of proteins for these types of zinc ions is well below that of most metal carrier proteins. Thus, many of these proteins must obtain the metal through some type of zinc chaperone, and there is now considerable evidence that suggests that various metal carrier proteins may perform this role. In these cases, the mechanism would most likely follow the shared ligand (Fig. 4b) or altered affinity mechanism
(Fig. 4c), although chemical changes that alter the affinities of these proteins for zinc cannot be fully ruled out.

Most of the characterized interactions between metal carrier proteins and $\mathrm{Zn}^{2+}$-dependent proteins have entailed the transfer of $\mathrm{Zn}^{2+}$ ions from a $\mathrm{Zn}^{2+}$-dependent donor protein to a metal carrier protein. This usually involves the chelation of $\mathrm{Zn}^{2+}$ ions from proteins with regulatory or structural zinc ions. Although many of these examples indicated that equilibrium transfer is the most likely mechanism, other mechanisms are plausible. There is experimental evidence demonstrating that the removal of catalytic $\mathrm{Zn}^{2+}$ ions by metal carrier proteins with lower affinities does occur under some circumstances. These transfers probably involve protein-protein interactions, as suggested by the shared ligand and altered affinities mechanisms (Fig. 4). While this may also represent a method of zinc buffering, it is also highly likely that these mechanisms may represent a means of regulating metal-dependent enzymes.

In some cases, changes in the immediate chemical environment may cause metalation or demetalation of proteins containing structural or regulatory $\mathrm{Zn}^{2+}$ ions. For example, during $\mathrm{Zn}^{2+}$ signaling, $\mathrm{Zn}^{2+}$ is released into the cytoplasm from internal stores and/or from interstitial fluid, rising to a concentration of $10^{-9} \mathrm{M}$ or higher. This could cause metalation of some proteins containing structural or regulatory $\mathrm{Zn}^{2+}$ ions, although the affinities of proteins for these types of ions appear to be low enough that these proteins would not likely be metalated from the free $\mathrm{Zn}^{2+}$ pool in this manner. Likewise, oxidative stress may cause the release of extra $\mathrm{Zn}^{2+}$ ions from redoxsensitive metal-binding proteins, causing a rise in free $\mathrm{Zn}^{2+}$ concentrations in the cell (Turan et al. 1997). This could potentially affect proteins with cysteinecontaining $\mathrm{Zn}^{2+}$-binding sites, such as MTs, causing the release of $\mathrm{Zn}^{2+}$ ions and making them available to other metal-dependent proteins and enzymes. This would particularly affect enzymes with lower $\mathrm{Zn}^{2+}$ affinities that are mostly unsaturated or partially saturated at physiological zinc concentrations. With ample experimental evidence that demonstrates metal transport proteins are capable of both donating or accepting $\mathrm{Zn}^{2+}$ ions to and from other proteins, it is a reasonable assumption that these proteins also play a major role in regulating them. 


\section{Biological significance and future directions}

$\mathrm{Zn}^{2+}$ is an essential cofactor for many proteins and enzymes, where it is involved in processes that range from participation in catalysis to structural stabilization to enzyme regulation. Although nearly $1 / 3$ of proteins bind $\mathrm{Zn}^{2+}$, little is known about the metalation and demetalation of $\mathrm{Zn}^{2+}$-dependent proteins and how these processes affect physiology. There are now many examples of metal carrier proteins that can regulate $\mathrm{Zn}^{2+}$-dependent enzymes by supplying or extracting metal ions from them. These interactions can affect many biological processes; thus, disturbances in these systems may be a part of the pathophysiology of many chronic diseases. For example, chelation of $\mathrm{Zn}^{2+}$ can impair the recruitment of neutrophils and inhibit their ability to degranulate, generate reactive oxygen species, or produce certain cytokines (Hasan et al. 2016). Zinc chelation also inhibits the phagocytic activity of macrophages (Gao et al. 2018). Thus, metal carrier proteins have the potential to regulate the activities of neutrophils and macrophages by regulating zinc availability as well as by altering the behavior of many $\mathrm{Zn}^{2+}$-dependent proteins that govern these behaviors. Neutrophil extracellular traps (NETs) bind MMP-9 and MMP-25, which can activate pro-MMP-2 and cause endothelial damage in some autoimmune conditions, such as systemic lupus erythematosus (Carmona-Rivera et al. 2015). The inhibition of MMP-2 and other MMPs by LTF, CP, and CALP thus has the potential to moderate both NET formation and MMP-2 activity. The release of CALP and LTF during NET formation may be a means of regulating these enzymes to mitigate tissue damage.

Excess $\mathrm{Zn}^{2+}$ can also impair the immune system and allow pathogens to evade both innate and adaptive responses (Rink and Kirchner 2000). It is thus feasible that the undesirable effects of excessively low or high $\mathrm{Zn}^{2+}$ concentrations may be mitigated through the use of metal carrier proteins to provide proper regulation of $\mathrm{Zn}^{2+}$-dependent proteins, or that chelation of excess $\mathrm{Zn}^{2+}$ by metal carrier proteins could be employed to treat autoimmune diseases such as rheumatoid arthritis by inhibiting the function of lymphocytes (Skrajnowska and Bobrowska-Korczak 2019). Deficiencies in metal carrier proteins in the presence of excessive amounts of $\mathrm{Zn}^{2+}$ can increase susceptibility to some pathogens, such as Clostridium difficile (Zackular et al. 2016).

Metal carrier proteins and the $\mathrm{Zn}^{2+}$-dependent enzymes that they regulate have also been implicated in immune responses to infectious agents. For example, elevated levels of LTF, S100A9, and MMP-9 have been highly correlated with mortality in COVID-19 patients (Abers et al. 2021). It is probable that the elevated levels of one or more of these metal carrier proteins may be responsible for dysfunctional regulation of enzymes needed for proper immune responses, or that the presence of metal carrier proteins are misdirecting the immune response in a way that hampers its ability to contain the virus and to properly regulate cytokine expression.

Many pathological conditions involve the activation of the NF- $\mathrm{BB}$ and $\mathrm{p} 38$ /MAPK signaling pathways. Although both pathways are highly activated by $\mathrm{Zn}^{2+}$, and although there have not yet been any direct observations of the involvement of metal carrier proteins in regulating these pathways, there are numerous studies that suggest it. For example, both pathways contribute to the secretion of cytokines and promotion of inflammation in atopic dermatitis, and a study indicated that administration of both S100A8 and S100A9 (CALP) in keratinocytes upregulates these pathways as well (Kim et al. 2019). Likewise, the inhibitory effect of $\mathrm{Zn}^{2+}$ on NF- $\mathrm{KB}$ activation can be lessened by increasing MT expression, potentially acting as an important check on these pathways (Kim et al. 2003).

Regardless of mechanism, the interaction of metal carrier proteins with $\mathrm{Zn}^{2+}$-dependent enzymes constitutes a novel means of protein regulation that is open for discovery. While the idea of regulating $\mathrm{Zn}^{2+}$ levels under nutritional deficiencies by accelerating protein degradation via autophagy (Ding and Zhong 2017) is not new, the mechanisms behind the distribution of the newly-liberated ions have not been fully dissected. Thus, is it possible that metal carrier proteins may play a role in this mechanism by reclaiming $\mathrm{Zn}^{2+}$ ions prior to or during protein degradation. In addition, the role of metal carrier proteins in reclaiming and redistributing $\mathrm{Zn}^{2+}$ ions under certain conditions, such as during oxidative stress, increased temperature, and inflammation, remains to be characterized. These findings also raise the possibility of targeting these mechanisms in the development of therapeutics for many pathophysiological conditions. Since $\mathrm{Zn}^{2+}$ 
is so critical to many physiological processes, disturbances in its availability have the potential to contribute to the pathophysiology of many chronic diseases. A firmer understanding of the role of metal carrier proteins in the bioavailability of $\mathrm{Zn}^{2+}$ and in the regulation of $\mathrm{Zn}^{2+}$-dependent proteins has the potential to improve the understanding of disease processes and assist in the development of appropriate therapeutics.

Acknowledgements This work was supported in part by University Research Council grant URC 20-18 (Indiana State University). The author would like to thank Dr. Louis B. Hersh and Dr. Kee-Yuen Martin Chow (University of Kentucky) for helpful suggestions regarding the manuscript.

Author contributions MWT, corresponding author.

Funding University Research Council URC 20-18, Indiana State University.

Data availability Data available upon request.

Code availability Not applicable.

\section{Declarations}

Conflict of interest Not applicable.

\section{References}

Abers MS et al (2021) An immune-based biomarker signature is associated with mortality in COVID-19 patients. JCI Insight. https://doi.org/10.1172/jci.insight.144455

Adham NF, Song MK, Rinderknecht H (1977) Binding of zinc to alpha-2-macroglobulin and its role in enzyme binding activity. Biochim Biophys Acta 495:212-219. https://doi. org/10.1016/0005-2795(77)90378-6

Ainscough EW, Brodie AM, Plowman JE (1980) Zinc transport by lactoferrin in human milk. Am J Clin Nutr 33:13141315. https://doi.org/10.1093/ajcn/33.6.1314

Aisen P, Listowsky I (1980) Iron transport and storage proteins. Annu Rev Biochem 49:357-393. https://doi.org/10.1146/ annurev.bi.49.070180.002041

Andreini C, Banci L, Bertini I, Rosato A (2006) Counting the zinc-proteins encoded in the human genome. J Proteome Res 5:196-201. https://doi.org/10.1021/pr050361j

Argyris PP et al (2019) Intracellular calprotectin (S100A8/A9) controls epithelial differentiation and caspase-mediated cleavage of EGFR in head and neck squamous cell carcinoma. Oral Oncol 95:1-10. https://doi.org/10.1016/j. oraloncology.2019.05.027

Ataie NJ, Hoang QQ, Zahniser MP, Tu Y, Milne A, Petsko GA, Ringe D (2008) Zinc coordination geometry and ligand binding affinity: the structural and kinetic analysis of the second-shell serine 228 residue and the methionine 180 residue of the aminopeptidase from
Vibrio proteolyticus. Biochemistry 47:7673-7683. https://doi.org/10.1021/bi702188e

Atrian S, Capdevila M (2013) Metallothionein-protein interactions. Biomol Concepts 4:143-160. https://doi.org/ 10.1515/bmc-2012-0049

Baker HM, Baker EN (2004) Lactoferrin and iron: structural and dynamic aspects of binding and release. Biometals 17:209-216. https://doi.org/10.1023/b:biom.00000 27694.40260.70

Baker HM, Baker CJ, Smith CA, Baker EN (2000) Metal substitution in transferrins: specific binding of cerium(IV) revealed by the crystal structure of cerium-substituted human lactoferrin. J Biol Inorg Chem 5:692-698. https://doi.org/10.1007/s007750000157

Baker HM, Anderson BF, Baker EN (2003) Dealing with iron: common structural principles in proteins that transport iron and heme. Proc Natl Acad Sci USA 100:3579-3583. https://doi.org/10.1073/pnas.06372 95100

Baltaci AK, Yuce K (2018) Zinc transporter proteins. Neurochem Res 43:517-530. https://doi.org/10.1007/ s11064-017-2454-y

Baudier J, Glasser N, Gerard D (1986) Ions binding to S100 proteins. I. Calcium- and zinc-binding properties of bovine brain S100 alpha alpha, S100a (alpha beta), and S100b (beta beta) protein: $\mathrm{Zn} 2+$ regulates $\mathrm{Ca} 2+$ binding on S100b protein. J Biol Chem 261:8192-8203

Bento I, Martins LO, Gato Lopes G, Armenia Carrondo M, Lindley PF (2005) Dioxygen reduction by multi-copper oxidases; a structural perspective. Dalton Trans. https:// doi.org/10.1039/b504806k

Berkovits HJ, Berg JM (1999) Metal and DNA binding properties of a two-domain fragment of neural zinc finger factor 1, a CCHC-type zinc binding protein. Biochemistry 38:16826-16830. https://doi.org/10.1021/bi9914331

Bertini I, Luchinat C, Monnanni R (1985) Zinc enzymes. J Chem Educ 62:924-927. https://doi.org/10.1021/ed062 p924

Bertini I, Luchinat C, Rosi M, Sgamellotti A, Tarantelli F (1990) $\mathrm{pKa}$ of zinc-bound water and nucleophilicity of hydroxo-containing species. Ab initio calculations on models for zinc enzymes. Inorg Chem 29:1460-1463. https://doi.org/10.1021/ic00333a004

Besold AN et al (2018) Role of calprotectin in withholding zinc and copper from Candida albicans. Infect Immun. https://doi.org/10.1128/iai.00779-17

Blakeborough P, Salter DN, Gurr MI (1983) Zinc binding in cow's milk and human milk. Biochem J 209:505-512. https://doi.org/10.1042/bj2090505

Brand IA, Heinickel A (1991) Key enzymes of carbohydrate metabolism as targets of the $11.5-\mathrm{kDa} \mathrm{Zn}(2+)$-binding protein (parathymosin). J Biol Chem 266:20984-20989

Brand IA, Soling HD (1986) Zn2+-dependent reversible inactivation of rat liver phosphofructokinase-1. Purification of the inactivating protein and characterization of the inactivation reaction. J Biol Chem 261:5892-5900

Braun W, Vasak M, Robbins AH, Stout CD, Wagner G, Kagi JH, Wuthrich K (1992) Comparison of the NMR solution structure and the x-ray crystal structure of rat metallothionein-2. Proc Natl Acad Sci USA 89:10124-10128. https://doi.org/10.1073/pnas.89.21.10124 
Brock JH (2012) Lactoferrin-50 years on. Biochem Cell Biol 90:245-251. https://doi.org/10.1139/o2012-018

Brodersen DE, Nyborg J, Kjeldgaard M (1999) Zinc-binding site of an S100 protein revealed. Two crystal structures of $\mathrm{Ca} 2+-$ bound human psoriasin (S100A7) in the $\mathrm{Zn2+-}$ loaded and Zn2+-free states. Biochemistry 38:16951704. https://doi.org/10.1021/bi982483d

Brooks PC, Silletti S, von Schalscha TL, Friedlander M, Cheresh DA (1998) Disruption of angiogenesis by PEX, a noncatalytic metalloproteinase fragment with integrin binding activity. Cell 92:391-400. https://doi.org/10. 1016/s0092-8674(00)80931-9

Cano-Gauci DF, Sarkar B (1996) Reversible zinc exchange between metallothionein and the estrogen receptor zinc finger. FEBS Lett 386:1-4. https://doi.org/10.1016/00145793(96)00356-0

Carmona-Rivera C, Zhao W, Yalavarthi S, Kaplan MJ (2015) Neutrophil extracellular traps induce endothelial dysfunction in systemic lupus erythematosus through the activation of matrix metalloproteinase-2. Ann Rheum Dis 74:1417-1424. https://doi.org/10.1136/annrh eumdis-2013-204837

Chacon KN et al (2018) Trapping intermediates in metal transfer reactions of the CusCBAF export pump of Escherichia Coli. Commun Biol 1:192. https://doi.org/10.1038/ s42003-018-0181-9

Christianson DW, Cox JD (1999) Catalysis by metal-activated hydroxide in zinc and manganese metalloenzymes. Annu Rev Biochem 68:33-57. https://doi.org/10.1146/annurev. biochem.68.1.33

Chung RS et al (2008) Redefining the role of metallothionein within the injured brain: extracellular metallothioneins play an important role in the astrocyte-neuron response to injury. J Biol Chem 283:15349-15358. https://doi.org/ 10.1074/jbc.M708446200

Cikot $\mathrm{M}$ et al (2016) Plasma calprotectin level: usage in distinction of uncomplicated from complicated acute appendicitis. World J Emerg Surg 11:7. https://doi.org/10. 1186/s13017-016-0062-9

Colvin RA, Holmes WR, Fontaine CP, Maret W (2010) Cytosolic zinc buffering and muffling: their role in intracellular zinc homeostasis. Metallomics 2:306-317. https://doi. org/10.1039/b926662c

Costello LC, Liu Y, Franklin RB, Kennedy MC (1997) Zinc inhibition of mitochondrial aconitase and its importance in citrate metabolism of prostate epithelial cells. J Biol Chem 272:28875-28881. https://doi.org/10.1074/jbc. 272.46.28875

Crow JP, Sampson JB, Zhuang Y, Thompson JA, Beckman JS (1997) Decreased zinc affinity of amyotrophic lateral sclerosis-associated superoxide dismutase mutants leads to enhanced catalysis of tyrosine nitration by peroxynitrite. J Neurochem 69:1936-1944. https://doi.org/10. 1046/j.1471-4159.1997.69051936.x

Cunden LS, Gaillard A, Nolan EM (2016) Calcium ions tune the zinc-sequestering properties and antimicrobial activity of human S100A12. Chem Sci 7:1338-1348. https:// doi.org/10.1039/C5SC03655K

Damo SM et al (2013) Molecular basis for manganese sequestration by calprotectin and roles in the innate immune response to invading bacterial pathogens. Proc Natl Acad
Sci USA 110:3841-3846. https://doi.org/10.1073/pnas. 1220341110

Dashper SG et al (2012) Lactoferrin inhibits Porphyromonas gingivalis proteinases and has sustained biofilm inhibitory activity. Antimicrob Agents Chemother 56:15481556. https://doi.org/10.1128/AAC.05100-11

Day ES et al (1999) Zinc-dependent structural stability of human Sonic hedgehog. Biochemistry 38:14868-14880. https://doi.org/10.1021/bi9910068

Dell'Angelica EC, Schleicher CH, Santome JA (1994) Primary structure and binding properties of calgranulin $\mathrm{C}$, a novel S100-like calcium-binding protein from pig granulocytes. J Biol Chem 269:28929-28936

Ding B, Zhong Q (2017) Zinc deficiency: an unexpected trigger for autophagy. J Biol Chem 292:8531-8532. https:// doi.org/10.1074/jbc.H116.762948

Donato R, Cannon BR, Sorci G, Riuzzi F, Hsu K, Weber DJ, Geczy CL (2013) Functions of S100 proteins. Curr Mol Med 13:24-57

Dutta A, Bahar I (2010) Metal-binding sites are designed to achieve optimal mechanical and signaling properties. Structure 18:1140-1148. https://doi.org/10.1016/j.str. 2010.06.013

Ehrchen JM, Sunderkotter C, Foell D, Vogl T, Roth J (2009) The endogenous toll-like receptor 4 agonist S100A8/ S100A9 (calprotectin) as innate amplifier of infection, autoimmunity, and cancer. J Leukoc Biol 86:557-566. https://doi.org/10.1189/jlb.1008647

Evers TH, Appelhof MA, Meijer EW, Merkx M (2008) Histags as $\mathrm{Zn}(\mathrm{II})$ binding motifs in a protein-based fluorescent sensor. Protein Eng Des Sel 21:529-536. https://doi. org/10.1093/protein/gzn029

Fagerhol M, Andersson K, Naess-Andresen C, Brandtzaeg P, Dale I (1990) Calprotectin (The L1 Leukocyte Protein). In: Smith VL, Dedman JR (eds) Stimulus response coupling. The role of intracellular calcium-binding proteins. CRC Press, Boca Raton

Farnaud S, Evans RW (2003) Lactoferrin-a multifunctional protein with antimicrobial properties. Mol Immunol 40:395-405. https://doi.org/10.1016/S0161-5890(03) 00152-4

Feng W, Cai J, Pierce WM, Franklin RB, Maret W, Benz FW, Kang YJ (2005) Metallothionein transfers zinc to mitochondrial aconitase through a direct interaction in mouse hearts. Biochem Biophys Res Commun 332:853-858. https://doi.org/10.1016/j.bbrc.2005.04.170

Filipek A, Heizmann CW, Kuznicki J (1990) Calcyclin is a calcium and zinc binding protein. FEBS Lett 264:263-266. https://doi.org/10.1016/0014-5793(90)80263-i

Filipek A, Michowski W, Kuznicki J (2008) Involvement of S100A6 (calcyclin) and its binding partners in intracellular signaling pathways. Adv Enzyme Regul 48:225-239. https://doi.org/10.1016/j.advenzreg.2007.11.001

Foell D et al (2003) Expression of the pro-inflammatory protein S100A12 (EN-RAGE) in rheumatoid and psoriatic arthritis. Rheumatology (Oxford) 42:1383-1389. https:// doi.org/10.1093/rheumatology/keg385

Fohr UG, Heizmann CW, Engelkamp D, Schafer BW, Cox JA (1995) Purification and cation binding properties of the recombinant human $\mathrm{S} 100$ calcium-binding protein $\mathrm{A} 3$, an EF-hand motif protein with high affinity for zinc. $\mathrm{J}$ 
Biol Chem 270:21056-21061. https://doi.org/10.1074/ jbc.270.36.21056

Foster AW, Osman D, Robinson NJ (2014) Metal preferences and metallation. J Biol Chem 289:28095-28103. https:// doi.org/10.1074/jbc.R114.588145

Franklin RB, Milon B, Feng P, Costello LC (2005) Zinc and zinc transporters in normal prostate and the pathogenesis of prostate cancer. Front Biosci 10:2230-2239. https:// doi.org/10.2741/1692

Fujimoto S et al (2016) The PP-motif in luminal loop 2 of ZnT transporters plays a pivotal role in TNAP activation. Biochem J 473:2611-2621. https://doi.org/10.1042/BCJ20 160324

Fukada T, Kambe T (2014) Zinc signals in cellular functions and disorders. Springer, Tokyo, New York. https://doi. org/10.1007/978-4-431-55114-0

Fukasawa KM, Hata T, Ono Y, Hirose J (2011) Metal preferences of zinc-binding motif on metalloproteases. J Amino Acids 2011:574816. https://doi.org/10.4061/ 2011/574816

Fukunaka A et al (2011) Tissue nonspecific alkaline phosphatase is activated via a two-step mechanism by zinc transport complexes in the early secretory pathway. J Biol Chem 286:16363-16373. https://doi.org/10.1074/ jbc.M111.227173

Furmanski P, Li ZP (1990) Multiple forms of lactoferrin in normal and leukemic human granulocytes. Exp Hematol 18:932-935

Gao H, Dai W, Zhao L, Min J, Wang F (2018) The role of zinc and zinc homeostasis in macrophage function. J Immunol Res 2018:6872621. https://doi.org/10.1155/2018/68726 21

Goering PL, Fowler BA (1987) Regulatory roles of high-affinity metal-binding proteins in mediating lead effects on delta-aminolevulinic acid dehydratase. Ann N Y Acad Sci 514:235-247. https://doi.org/10.1111/j.1749-6632. 1987.tb48778.x

Goyette J et al (2009) Pleiotropic roles of S100A12 in coronary atherosclerotic plaque formation and rupture. J Immunol 183:593-603. https://doi.org/10.4049/jimmunol.0900373

Guerrerio AL, Berg JM (2004) Metal ion affinities of the zinc finger domains of the metal responsive element-binding transcription factor-1 (MTF1). Biochemistry 43:54375444. https://doi.org/10.1021/bi0358418

Guignard F, Mauel J, Markert M (1996) Phosphorylation of myeloid-related proteins MRP-14 and MRP-8 during human neutrophil activation. Eur J Biochem 241:265271. https://doi.org/10.1111/j.1432-1033.1996.0265t.x

Haase H, Maret W (2003) Intracellular zinc fluctuations modulate protein tyrosine phosphatase activity in insulin/insulin-like growth factor-1 signaling. Exp Cell Res 291:289298. https://doi.org/10.1016/s0014-4827(03)00406-3

Hannappel E, Huff T (2003) The thymosins. Prothymosin alpha, parathymosin, and beta-thymosins: structure and function. Vitam Horm 66:257-296. https://doi.org/10. 1016/s0083-6729(03)01007-0

Hao Q, Hong SH, Maret W (2007) Lipid raft-dependent endocytosis of metallothionein in HepG2 cells. J Cell Physiol 210:428-435. https://doi.org/10.1002/jcp.20874

Harrington JP (1992) Spectroscopic analysis of the unfolding of transition metal-ion complexes of human lactoferrin and transferrin. Int J Biochem 24:275-280. https://doi. org/10.1016/0020-711x(92)90258-3

Harris WR (1983) Thermodynamic binding constants of the zinc-human serum transferrin complex. Biochemistry 22:3920-3926. https://doi.org/10.1021/bi00285a030

Harris ZL, Durley AP, Man TK, Gitlin JD (1999) Targeted gene disruption reveals an essential role for ceruloplasmin in cellular iron efflux. Proc Natl Acad Sci USA 96:10812-10817. https://doi.org/10.1073/pnas.96.19. 10812

Hasan R, Rink L, Haase H (2016) Chelation of free $\mathrm{Zn}(2)$ (+) impairs chemotaxis, phagocytosis, oxidative burst, degranulation, and cytokine production by neutrophil granulocytes. Biol Trace Elem Res 171:79-88. https:// doi.org/10.1007/s12011-015-0515-0

Hasler DW, Jensen LT, Zerbe O, Winge DR, Vasak M (2000) Effect of the two conserved prolines of human growth inhibitory factor (metallothionein-3) on its biological activity and structure fluctuation: comparison with a mutant protein. Biochemistry 39:14567-14575. https:// doi.org/10.1021/bi001569f

Hathout Y, Fabris D, Fenselau C (2001) Stoichiometry in zinc ion transfer from metallothionein to zinc finger peptides. Int J Mass Spectrom 204:1-6. https://doi.org/10.1016/ S1387-3806(00)00343-2

Hellman NE, Gitlin JD (2002) Ceruloplasmin metabolism and function. Annu Rev Nutr 22:439-458. https://doi.org/10. 1146/annurev.nutr.22.012502.114457

Hirano K, Ogihara T, Ogihara H, Hiroi M, Hasegawa M, Tamai $\mathrm{H}$ (2005) Identification of apo- and holo-forms of ceruloplasmin in patients with Wilson's disease using native polyacrylamide gel electrophoresis. Clin Biochem 38:912. https://doi.org/10.1016/j.clinbiochem.2004.09.008

Hirose $\mathrm{J}$ et al (2006) Characterization of the metal-binding site in aminopeptidase B. Biol Pharm Bull 29:2378-2382. https://doi.org/10.1248/bpb.29.2378

Hogstrand C, Verbost PM, Wendelaar Bonga SE (1999) Inhibition of human erythrocyte Ca2+-ATPase by $\mathrm{Zn} 2+$. Toxicology 133:139-145. https://doi.org/10.1016/s0300483x(99)00020-7

Huang M, Shaw IC, Petering DH (2004) Interprotein metal exchange between transcription factor IIIa and apo-metallothionein. J Inorg Biochem 98:639-648. https://doi. org/10.1016/j.jinorgbio.2004.02.004

Huber KL, Hardy JA (2012) Mechanism of zinc-mediated inhibition of caspase-9. Protein Sci 21:1056-1065. https:// doi.org/10.1002/pro.2090

Ikeda T, Kimura K, Morioka S, Tamaki N (1980) Inhibitory effects of $\mathrm{Zn} 2+$ on muscle glycolysis and their reversal by histidine. J Nutr Sci Vitaminol (tokyo) 26:357-366. https://doi.org/10.3177/jnsv.26.357

Imanishi M, Matsumura K, Tsuji S, Nakaya T, Negi S, Futaki S, Sugiura Y (2012) Zn(II) binding and DNA binding properties of ligand-substituted CXHH-type zinc finger proteins. Biochemistry 51:3342-3348. https://doi.org/10. 1021/bi300236m

Isaksen B, Fagerhol MK (2001) Calprotectin inhibits matrix metalloproteinases by sequestration of zinc. Mol Pathol 54:289-292. https://doi.org/10.1136/mp.54.5.289

Jabeen T, Sharma S, Singh N, Bhushan A, Singh TP (2005) Structure of the zinc-saturated C-terminal lobe of 
bovine lactoferrin at 2.0 A resolution. Acta Crystallogr D Biol Crystallogr 61:1107-1115. https://doi.org/10. 1107/S0907444905016069

Jabrani A et al (2017) biophysical characterisation of the novel zinc binding property in suppressor of fused. Sci Rep 7:11139. https://doi.org/10.1038/ s41598-017-11203-2

Jacob C, Maret W, Vallee BL (1998) Control of zinc transfer between thionein, metallothionein, and zinc proteins. Proc Natl Acad Sci USA 95:3489-3494. https://doi.org/ 10.1073/pnas.95.7.3489

Johne B, Fagerhol MK, Lyberg T, Prydz H, Brandtzaeg P, Naess-Andresen CF, Dale I (1997) Functional and clinical aspects of the myelomonocyte protein calprotectin. Mol Pathol 50:113-123. https://doi.org/10.1136/mp.50.3. 113

Kambe T (2014) Introduction: "Zinc Signaling"-The Blossoming Field of Zinc Biology. In: Fukada T, Kambe T (eds) Zinc Signals in Cellular Functions and Disorders. Springer Japan, Tokyo, pp 1-5. https://doi.org/10.1007/ 978-4-431-55114-0_1

Kambe T, Takeda TA, Nishito Y (2016) Activation of zincrequiring ectoenzymes by $\mathrm{ZnT}$ transporters during the secretory process: biochemical and molecular aspects. Arch Biochem Biophys 611:37-42. https://doi.org/10. 1016/j.abb.2016.03.035

Kammerman MT et al (2020) Molecular insight into TdfHmediated zinc piracy from human calprotectin by Neisseria gonorrhoeae. Mbio. https://doi.org/10.1128/mBio. 00949-20

Kawasaki H, Nakayama S, Kretsinger RH (1998) Classification and evolution of EF-hand proteins. Biometals 11:277295. https://doi.org/10.1023/a:1009282307967

Kim CH, Kim JH, Lee J, Ahn YS (2003) Zinc-induced NFkappaB inhibition can be modulated by changes in the intracellular metallothionein level. Toxicol Appl Pharmacol 190:189-196. https://doi.org/10.1016/s0041008x(03)00167-4

Kim MJ, Im MA, Lee JS, Mun JY, Kim DH, Gu A, Kim IS (2019) Effect of S100A8 and S100A9 on expressions of cytokine and skin barrier protein in human keratinocytes. Mol Med Rep 20:2476-2483. https://doi.org/10.3892/ mmr.2019.10454

Kim JK et al (2020) Elucidating the role of metal ions in carbonic anhydrase catalysis. Nat Commun 11:4557. https:// doi.org/10.1038/s41467-020-18425-5

Kimura T, Kambe T (2016) The functions of metallothionein and ZIP and ZnT transporters: an overview and perspective. Int J Mol Sci 17:336. https://doi.org/10.3390/ijms1 7030336

Kluska K, Adamczyk J, Krezel A (2018a) Metal binding properties of zinc fingers with a naturally altered metal binding site. Metallomics 10:248-263. https://doi.org/10. 1039/c7mt00256d

Kluska K, Adamczyk J, Krezel A (2018b) Metal binding properties, stability and reactivity of zinc fingers. Coordin Chem Rev 367:18-64

Knipp M, Charnock JM, Garner CD, Vasak M (2001) Structural and functional characterization of the $\mathrm{Zn}$ (II) site in dimethylargininase-1 (DDAH-1) from bovine brain. $\mathrm{Zn}(\mathrm{II})$ release activates DDAH-1. J Biol Chem
276:40449-40456. https://doi.org/10.1074/jbc.M1040 56200

Kochanczyk T, Drozd A, Krezel A (2015) Relationship between the architecture of zinc coordination and zinc binding affinity in proteins-insights into zinc regulation. Metallomics 7:244-257. https://doi.org/10.1039/c4mt0 0094c

Kooi C, Subsin B, Chen R, Pohorelic B, Sokol PA (2006) Burkholderia cenocepacia $\mathrm{ZmpB}$ is a broad-specificity zinc metalloprotease involved in virulence. Infect Immun 74:4083-4093. https://doi.org/10.1128/IAI.00297-06

Kordowska J, Stafford WF, Wang CL (1998) Ca2+ and Zn2+ bind to different sites and induce different conformational changes in human calcyclin. Eur J Biochem 253:57-66. https://doi.org/10.1046/j.1432-1327.1998.2530057.x

Kosaki A et al (2004) Increased plasma S100A12 (EN-RAGE) levels in patients with type 2 diabetes. J Clin Endocrinol Metab 89:5423-5428. https://doi.org/10.1210/jc. 2003-032223

Krezel A, Maret W (2007) Dual nanomolar and picomolar $\mathrm{Zn}$ (II) binding properties of metallothionein. J Am Chem Soc 129:10911-10921. https://doi.org/10.1021/ja071 979s

Krezel A, Maret W (2008) Thionein/metallothionein control $\mathrm{Zn}(\mathrm{II})$ availability and the activity of enzymes. J Biol Inorg Chem 13:401-409. https://doi.org/10.1007/ s00775-007-0330-y

Krezel A, Maret W (2016) The biological inorganic chemistry of zinc ions. Arch Biochem Biophys 611:3-19. https:// doi.org/10.1016/j.abb.2016.04.010

Krishna SS, Majumdar I, Grishin NV (2003) Structural classification of zinc fingers: survey and summary. Nucleic Acids Res 31:532-550. https://doi.org/10.1093/nar/ gkg161

Kruzel ML et al (2013) Novel recombinant human lactoferrin: differential activation of oxidative stress related gene expression. J Biotechnol 168:666-675. https://doi.org/10. 1016/j.jbiotec.2013.09.011

Laitaoja M, Valjakka J, Janis J (2013) Zinc coordination spheres in protein structures. Inorg Chem 52:1098310991. https://doi.org/10.1021/ic401072d

Lambert LA, Perri H, Halbrooks PJ, Mason AB (2005) Evolution of the transferrin family: conservation of residues associated with iron and anion binding. Comp Biochem Physiol B Biochem Mol Biol 142:129-141. https://doi. org/10.1016/j.cbpb.2005.07.007

Larsen KS, Auld DS (1991) Characterization of an inhibitory metal binding site in carboxypeptidase A. Biochemistry 30:2613-2618. https://doi.org/10.1021/bi00224a007

Li TY, Kraker AJ, Shaw CF 3rd, Petering DH (1980) Ligand substitution reactions of metallothioneins with EDTA and apo-carbonic anhydrase. Proc Natl Acad Sci USA 77:6334-6338. https://doi.org/10.1073/pnas.77.11.6334

Li S, Zhou H, Huang G, Liu N (2009) Inhibition of HBV infection by bovine lactoferrin and iron-, zinc-saturated lactoferrin. Med Microbiol Immunol 198:19-25. https://doi. org/10.1007/s00430-008-0100-7

Lin H, Andersen GR, Yatime L (2016) Crystal structure of human S100A8 in complex with zinc and calcium. BMC Struct Biol 16:8. https://doi.org/10.1186/ s12900-016-0058-4 
Linder MC (2016) Ceruloplasmin and other copper binding components of blood plasma and their functions: an update. Metallomics 8:887-905. https://doi.org/10. 1039/c6mt00103c

Lindley PF, Card G, Zaitseva I, Zaitsev V, Reinhammar B, Selin-Lindgren E, Yoshida K (1997) An X-ray structural study of human ceruloplasmin in relation to ferroxidase activity JBIC. J Biol Inorg Chem 2:454-463. https://doi.org/10.1007/s007750050156

Liu JZ et al (2012) Zinc sequestration by the neutrophil protein calprotectin enhances Salmonella growth in the inflamed gut. Cell Host Microbe 11:227-239. https:// doi.org/10.1016/j.chom.2012.01.017

Lu D, Searles MA, Klug A (2003) Crystal structure of a zincfinger-RNA complex reveals two modes of molecular recognition. Nature 426:96-100. https://doi.org/10. 1038/nature02088

Magneson GR, Puvathingal JM, Ray WJ Jr (1987) The concentrations of free $\mathrm{Mg} 2+$ and free $\mathrm{Zn} 2+$ in equine blood plasma. J Biol Chem 262:11140-11148

Makowski GS, Sunderman FW Jr (1992) The interactions of zinc, nickel, and cadmium with Xenopus transcription factor IIIA, assessed by equilibrium dialysis. J Inorg Biochem 48:107-119. https://doi.org/10.1016/01620134(92)80020-v

Maler L, Potts BC, Chazin WJ (1999) High resolution solution structure of apo calcyclin and structural variations in the S100 family of calcium-binding proteins. J Biomol NMR 13:233-247. https://doi.org/10.1023/a:10083 15517955

Marchetti M, Pisani S, Antonini G, Valenti P, Seganti L, Orsi N (1998) Metal complexes of bovine lactoferrin inhibit in vitro replication of herpes simplex virus type 1 and 2. Biometals 11:89-94. https://doi.org/10.1023/a:10092 17709851

Marchetti M, Superti F, Ammendolia MG, Rossi P, Valenti P, Seganti L (1999) Inhibition of poliovirus type 1 infection by iron-, manganese- and zinc-saturated lactoferrin. Med Microbiol Immunol 187:199-204. https://doi.org/10. 1007/s004300050093

Marenholz I, Heizmann CW, Fritz G (2004) S100 proteins in mouse and man: from evolution to function and pathology (including an update of the nomenclature). Biochem Biophys Res Commun 322:1111-1122. https://doi.org/ 10.1016/j.bbrc.2004.07.096

Maret W (2004) Zinc and sulfur: a critical biological partnership. Biochemistry 43:3301-3309. https://doi.org/10. 1021/bi036340p

Maret W (2011) Metals on the move: zinc ions in cellular regulation and in the coordination dynamics of zinc proteins. Biometals 24:411-418. https://doi.org/10.1007/ s10534-010-9406-1

Maret W (2013a) Inhibitory zinc sites in enzymes. Biometals 26:197-204. https://doi.org/10.1007/s10534-013-9613-7

Maret W (2013b) Zinc biochemistry: from a single zinc enzyme to a key element of life. Adv Nutr 4:82-91. https://doi.org/10.3945/an.112.003038

Maret W, Vallee BL (1998) Thiolate ligands in metallothionein confer redox activity on zinc clusters. Proc Natl Acad Sci USA 95:3478-3482. https://doi.org/10.1073/pnas.95.7. 3478
Maret W, Jacob C, Vallee BL, Fischer EH (1999) Inhibitory sites in enzymes: zinc removal and reactivation by thionein. Proc Natl Acad Sci USA 96:1936-1940. https://doi. org/10.1073/pnas.96.5.1936

Masters BA, Kelly EJ, Quaife CJ, Brinster RL, Palmiter RD (1994a) Targeted disruption of metallothionein I and II genes increases sensitivity to cadmium. Proc Natl Acad Sci USA 91:584-588. https://doi.org/10.1073/pnas.91.2. 584

Masters BA et al (1994b) Metallothionein III is expressed in neurons that sequester zinc in synaptic vesicles. J Neurosci 14:5844-5857

Matthews BW (1988) Structural basis of the action of thermolysin and related zinc peptidases. Acc Chem Res 21:333340. https://doi.org/10.1021/ar00153a003

Maurakis S, Keller K, Maxwell CN, Pereira K, Chazin WJ, Criss AK, Cornelissen CN (2019) The novel interaction between Neisseria gonorrhoeae TdfJ and human S100A7 allows gonococci to subvert host zinc restriction. PLoS Pathog 15:e1007937. https://doi.org/10.1371/journal. ppat. 1007937

McCall KA, Fierke CA (2000) Colorimetric and fluorimetric assays to quantitate micromolar concentrations of transition metals. Anal Biochem 284:307-315. https://doi.org/ 10.1006/abio.2000.4706

McKee DJ, Frieden E (1971) Binding of transition metal ions by ceruloplasmin (ferroxidase). Biochemistry 10:38803883. https://doi.org/10.1021/bi00797a013

Meplan C, Richard MJ, Hainaut P (2000) Metalloregulation of the tumor suppressor protein p53: zinc mediates the renaturation of p53 after exposure to metal chelators in vitro and in intact cells. Oncogene 19:5227-5236. https://doi. org/10.1038/sj.onc. 1203907

Middleton RB, Linder MC (1993) Synthesis and turnover of ceruloplasmin in rats treated with 17 beta-estradiol. Arch Biochem Biophys 302:362-368. https://doi.org/10.1006/ abbi.1993.1224

Miloch A, Krezel A (2014) Metal binding properties of the zinc finger metallome-insights into variations in stability. Metallomics 6:2015-2024. https://doi.org/10.1039/ c4mt00149d

Moleirinho A, Carneiro J, Matthiesen R, Silva RM, Amorim A, Azevedo L (2011) Gains, losses and changes of function after gene duplication: study of the metallothionein family. PLoS ONE 6:e18487. https://doi.org/10.1371/journ al.pone.0018487

Moroz OV et al (2009) Both $\mathrm{Ca} 2+$ and $\mathrm{Zn} 2+$ are essential for S100A12 protein oligomerization and function. BMC Biochem 10:11. https://doi.org/10.1186/ 1471-2091-10-11

Muñoz A, Rodríguez AR (1995) Electrochemical behavior of metallothioneins and related molecules. Part III: metallothionein. Electroanalysis 7:674-680. https://doi.org/10. 1002/elan.1140070715

Murray JI et al (2012) Structural characterization of S100A15 reveals a novel zinc coordination site among S100 proteins and altered surface chemistry with functional implications for receptor binding. BMC Struct Biol 12:16. https://doi.org/10.1186/1472-6807-12-16

Neupane DP, Fullam SH, Chacon KN, Yukl ET (2019) Crystal structures of AztD provide mechanistic insights into 
direct zinc transfer between proteins. Commun Biol 2:308. https://doi.org/10.1038/s42003-019-0542-z

Newsome AL, Johnson JP, Seipelt RL, Thompson MW (2007) Apolactoferrin inhibits the catalytic domain of matrix metalloproteinase- 2 by zinc chelation. Biochem Cell Biol 85:563-572. https://doi.org/10.1139/o07-073

Ohyoshi E, Hamada Y, Nakata K, Kohata S (1999) The interaction between human and bovine serum albumin and zinc studied by a competitive spectrophotometry. J Inorg Biochem 75:213-218. https://doi.org/10.1016/s01620134(99)00090-2

Okubo K et al (2016) Lactoferrin suppresses neutrophil extracellular traps release in inflammation. EBioMedicine 10:204-215. https://doi.org/10.1016/j.ebiom.2016.07. 012

Ostrakhovitch EA, Olsson PE, Jiang S, Cherian MG (2006) Interaction of metallothionein with tumor suppressor p53 protein. FEBS Lett 580:1235-1238. https://doi.org/10. 1016/j.febslet.2006.01.036

Pabon ML, Lonnerdal B (2000) Bioavailability of zinc and its binding to casein in milks and formulas. J Trace Elem Med Biol 14:146-153. https://doi.org/10.1016/S0946672X(00)80003-6

Palmiter RD, Findley SD, Whitmore TE, Durnam DM (1992) MT-III, a brain-specific member of the metallothionein gene family. Proc Natl Acad Sci USA 89:6333-6337. https://doi.org/10.1073/pnas.89.14.6333

Payne JC, Rous BW, Tenderholt AL, Godwin HA (2003) Spectroscopic determination of the binding affinity of zinc to the DNA-binding domains of nuclear hormone receptors. Biochemistry 42:14214-14224. https://doi.org/10.1021/ bi0350021

Permyakov SE, Oberg KA, Cherskaya AM, Shavlovsky MM, Permyakov EA, Uversky VN (2002) Human alpha-fetoprotein as a $\mathrm{Zn}(2+)$-binding protein. Tight cation binding is not accompanied by global changes in protein structure and stability. Biochim Biophys Acta 1586:1-10. https:// doi.org/10.1016/s0925-4439(01)00079-5

Pontremoli S, Melloni E, Salamino F, Sparatore B, Horecker $\mathrm{BL}$ (1978) Interactions of $\mathrm{Zn} 2+$ and $\mathrm{Mg} 2+$ with rabbit liver fructose 1,6 bisphosphatase. Arch Biochem Biophys 188:90-97. https://doi.org/10.1016/0003-9861(78) 90360-0

Posewitz MC, Wilcox DE (1995) Properties of the Sp1 zinc finger 3 peptide: coordination chemistry, redox reactions, and metal binding competition with metallothionein. Chem Res Toxicol 8:1020-1028. https://doi.org/10.1021/ tx00050a005

Prasad AS, Brewer GJ, Schoomaker EB, Rabbani P (1978) Hypocupremia induced by zinc therapy in adults. JAMA 240:2166-2168

Pratt CW, Pizzo SV (1984) The effect of zinc and other divalent cations on the structure and function of human alpha 2-macroglobulin. Biochim Biophys Acta 791:123-130. https://doi.org/10.1016/0167-4838(84)90002-5

Quaife CJ, Findley SD, Erickson JC, Froelick GJ, Kelly EJ, Zambrowicz BP, Palmiter RD (1994) Induction of a new metallothionein isoform (MT-IV) occurs during differentiation of stratified squamous epithelia. Biochemistry 33:7250-7259. https://doi.org/10.1021/bi00189a029
Raftery MJ, Harrison CA, Alewood P, Jones A, Geczy CL (1996) Isolation of the murine S100 protein MRP14 (14 $\mathrm{kDa}$ migration-inhibitory-factor-related protein) from activated spleen cells: characterization of post-translational modifications and zinc binding. Biochem J 316(Pt 1):285-293. https://doi.org/10.1042/bj3160285

Randazzo A, Acklin C, Schafer BW, Heizmann CW, Chazin WJ (2001) Structural insight into human $\mathrm{Zn}(2+)$-bound S100A2 from NMR and homology modeling. Biochem Biophys Res Commun 288:462-467. https://doi.org/10. 1006/bbrc. 2001.5793

Ravasi T et al (2004) Probing the S100 protein family through genomic and functional analysis. Genomics 84:10-22. https://doi.org/10.1016/j.ygeno.2004.02.002

Rich AM et al (2012) Thermodynamics of $\mathrm{Zn} 2+$ binding to Cys2His2 and Cys2HisCys zinc fingers and a Cys4 transcription factor site. J Am Chem Soc 134:10405-10418. https://doi.org/10.1021/ja211417g

Rink L, Kirchner H (2000) Zinc-altered immune function and cytokine production. J Nutr 130:1407s-1411s. https:// doi.org/10.1093/jn/130.5.1407S

Roesijadi G, Bogumil R, Vasak M, Kagi JH (1998) Modulation of DNA binding of a tramtrack zinc finger peptide by the metallothionein-thionein conjugate pair. J Biol Chem 273:17425-17432. https://doi.org/10.1074/jbc.273.28. 17425

Rosa L, Cutone A, Lepanto MS, Paesano R, Valenti P (2017) Lactoferrin: a natural glycoprotein involved in iron and inflammatory homeostasis. Int J Mol Sci. https://doi.org/ 10.3390/ijms 18091985

Samygina VR, Sokolov AV, Pulina MO, Bartunik HD, Vasil'ev VB (2008) X-ray diffraction study of highly purified human ceruloplasmin. Crystallogr Rep 53:655. https:// doi.org/10.1134/S1063774508040172

Samygina VR et al (2013) Ceruloplasmin: macromolecular assemblies with iron-containing acute phase proteins. PLoS ONE 8:e67145. https://doi.org/10.1371/journal. pone. 0067145

Samygina VR et al (2017) Rat ceruloplasmin: a new labile copper binding site and zinc/copper mosaic. Metallomics 9:1828-1838. https://doi.org/10.1039/c7mt00157f

Schafer BW, Fritschy JM, Murmann P, Troxler H, Durussel I, Heizmann CW, Cox JA (2000) Brain S100A5 is a novel calcium-, zinc-, and copper ion-binding protein of the EF-hand superfamily. J Biol Chem 275:30623-30630. https://doi.org/10.1074/jbc.M002260200

Schullek JR, Wilson IB (1988) The binding of zinc to angiotensin-converting enzyme. Arch Biochem Biophys 265:346-350. https://doi.org/10.1016/0003-9861(88) 90137-3

Sehnal D et al (2021) Mol* Viewer: modern web app for 3D visualization and analysis of large biomolecular structures. Nucleic Acids Res 49:W431-W437. https://doi. org/10.1093/nar/gkab314

Sellin S, Mannervik B (1984) Metal dissociation constants for glyoxalase I reconstituted with $\mathrm{Zn} 2+, \mathrm{Co} 2+, \mathrm{Mn} 2+$, and Mg2+. J Biol Chem 259:11426-11429

Sen P, Sahoo S, Pendurthi UR, Rao LV (2010) Zinc modulates the interaction of protein $\mathrm{C}$ and activated protein $\mathrm{C}$ with endothelial cell protein $\mathrm{C}$ receptor. J Biol Chem 
285:20410-20420. https://doi.org/10.1074/jbc.M110. 111575

Si M, Lang J (2018) The roles of metallothioneins in carcinogenesis. J Hematol Oncol 11:107. https://doi.org/10. 1186/s13045-018-0645-x

Sikorska M, Krezel A, Otlewski J (2012) Femtomolar Zn2+ affinity of LIM domain of PDLIM1 protein uncovers crucial contribution of protein-protein interactions to protein stability. J Inorg Biochem 115:28-35. https://doi.org/10. 1016/j.jinorgbio.2012.05.009

Silva EJ, Argyris PP, Zou X, Ross KF, Herzberg MC (2014) S100A8/A9 regulates MMP-2 expression and invasion and migration by carcinoma cells. Int $\mathrm{J}$ Biochem Cell Biol 55:279-287. https://doi.org/10.1016/j.biocel.2014. 09.007

Skrajnowska D, Bobrowska-Korczak B (2019) Role of zinc in immune system and anti-cancer defense mechanisms. Nutrients 11:2273

Smith CA, Anderson BF, Baker HM, Baker EN (1992) Metal substitution in transferrins: the crystal structure of human copper-lactoferrin at 2.1-A resolution. Biochemistry 31:4527-4533. https://doi.org/10.1021/bi00133a020

Sohnle PG, Hunter MJ, Hahn B, Chazin WJ (2000) Zincreversible antimicrobial activity of recombinant calprotectin (migration inhibitory factor-related proteins 8 and 14). J Infect Dis 182:1272-1275. https://doi.org/10.1086/ 315810

Sokolov AV et al (2008) Ceruloplasmin and myeloperoxidase in complex affect the enzymatic properties of each other. Free Radic Res 42:989-998. https://doi.org/10.1080/ 10715760802566574

Sokolov AV, Pulina MO, Ageeva KV, Tcherkalina OS, Zakharova ET, Vasilyev VB (2009) Identification of complexes formed by ceruloplasmin with matrix metalloproteinases 2 and 12. Biochemistry (mosc) 74:13881392. https://doi.org/10.1134/s0006297909120141

Sokolov AV, Zakharova ET, Kostevich VA, Samygina VR, Vasilyev VB (2014) Lactoferrin, myeloperoxidase, and ceruloplasmin: complementary gearwheels cranking physiological and pathological processes. Biometals 27:815-828. https://doi.org/10.1007/s10534-014-9755-2

Spahl DU, Berendji-Grun D, Suschek CV, Kolb-Bachofen V, Kroncke KD (2003) Regulation of zinc homeostasis by inducible NO synthase-derived NO: nuclear metallothionein translocation and intranuclear $\mathrm{Zn} 2+$ release. Proc Natl Acad Sci USA 100:13952-13957. https://doi.org/10. 1073/pnas.2335190100

St Croix CM, Wasserloos KJ, Dineley KE, Reynolds IJ, Levitan ES, Pitt BR (2002) Nitric oxide-induced changes in intracellular zinc homeostasis are mediated by metallothionein/thionein. Am J Physiol Lung Cell Mol Physiol 282:L185-192. https://doi.org/10.1152/ajplung.00267. 2001

Stojanovic A, Stitham J, Hwa J (2004) Critical role of transmembrane segment zinc binding in the structure and function of rhodopsin. J Biol Chem 279:35932-35941. https://doi.org/10.1074/jbc.M403821200

Stork M et al (2013) Zinc piracy as a mechanism of Neisseria meningitidis for evasion of nutritional immunity. PLoS Pathog 9:e1003733. https://doi.org/10.1371/journal.ppat. 1003733
Strupat K, Rogniaux H, Van Dorsselaer A, Roth J, Vogl T (2000) Calcium-induced noncovalently linked tetramers of MRP8 and MRP14 are confirmed by electrospray ionization-mass analysis. J Am Soc Mass Spectrom 11:780788. https://doi.org/10.1016/S1044-0305(00)00150-1

Subramanian Vignesh K, Deepe GS Jr (2017) Metallothioneins: emerging modulators in Immunity and Infection. Int J Mol Sci. https://doi.org/10.3390/ijms18102197

Thompson MW (2012) Ceruloplasmin binds and inactivates matrix metalloproteinase-2. FASEB J. https://doi.org/10. 1096/fasebj.26.1_supplement.557.3

Thompson MW, Hersh LB (2003) Analysis of conserved residues of the human puromycin-sensitive aminopeptidase. Peptides 24:1359-1365. https://doi.org/10.1016/j.pepti des.2003.07.012

Thompson MW, Govindaswami M, Hersh LB (2003) Mutation of active site residues of the puromycin-sensitive aminopeptidase: conversion of the enzyme into a catalytically inactive binding protein. Arch Biochem Biophys 413:236-242. https://doi.org/10.1016/s0003-9861(03) 00123-1

Thompson MW, Archer ED, Romer CE, Seipelt RL (2006) A conserved tyrosine residue of Saccharomyces cerevisiae leukotriene A4 hydrolase stabilizes the transition state of the peptidase activity. Peptides 27:1701-1709. https:// doi.org/10.1016/j.peptides.2006.02.006

Trompeter HI, Brand IA, Soling HD (1989) The primary sequence of the PFK-1 inactivating zinc-binding protein as deduced from cDNA sequencing. Identity of the zinc-binding protein with rat parathymosin. FEBS Lett 253:63-66. https://doi.org/10.1016/0014-5793(89) 80930-5

Tsoporis JN, Izhar S, Desjardins JF, Leong-Poi H, Parker TG (2017) Abstract 16970: S100A6 interacts with melusin and attenuates stress-induced cardiomyocyte apoptosis. Circulation 136:A16970-A16970. https://doi.org/10. 1161/circ.136.suppl_1.16970

Turan B, Fliss H, Desilets M (1997) Oxidants increase intracellular free $\mathrm{Zn} 2+$ concentration in rabbit ventricular myocytes. Am J Physiol 272:H2095-2106. https://doi.org/10. 1152/ajpheart.1997.272.5.H2095

Udom AO, Brady FO (1980) Reactivation in vitro of zincrequiring apo-enzymes by rat liver zinc-thionein. Biochem J 187:329-335. https://doi.org/10.1042/bj1870329

Vallee BL, Auld DS (1990) Zinc coordination, function, and structure of zinc enzymes and other proteins. Biochemistry 29:5647-5659. https://doi.org/10.1021/bi00476a001

Vasilyev VB (2019) Looking for a partner: ceruloplasmin in protein-protein interactions. Biometals 32:195-210. https://doi.org/10.1007/s10534-019-00189-1

Velazquez-Delgado EM, Hardy JA (2012) Zinc-mediated allosteric inhibition of caspase-6. J Biol Chem 287:3600036011. https://doi.org/10.1074/jbc.M112.397752

Vinkenborg JL, Nicolson TJ, Bellomo EA, Koay MS, Rutter GA, Merkx M (2009) Genetically encoded FRET sensors to monitor intracellular $\mathrm{Zn} 2+$ homeostasis. Nat Methods 6:737-740. https://doi.org/10.1038/nmeth.1368

Vogl $\mathrm{T}$ et al (2018) Autoinhibitory regulation of S100A8/ S100A9 alarmin activity locally restricts sterile inflammation. J Clin Investig 128:1852-1866. https://doi.org/ 10.1172/JCI89867 
Vorum H, Madsen P, Rasmussen HH, Etzerodt M, Svendsen I, Celis JE, Honore B (1996) Expression and divalent cation binding properties of the novel chemotactic inflammatory protein psoriasin. Electrophoresis 17:1787-1796. https://doi.org/10.1002/elps.1150171118

Walker FJ, Fay PJ (1990) Characterization of an interaction between protein $\mathrm{C}$ and ceruloplasmin. $\mathrm{J}$ Biol Chem 265:1834-1836

Wang S, Song R, Wang Z, Jing Z, Wang S, Ma J (2018) S100A8/A9 in inflammation. Front Immunol 9:1298. https://doi.org/10.3389/fimmu.2018.01298

Wilder PT, Baldisseri DM, Udan R, Vallely KM, Weber DJ (2003) Location of the $\mathrm{Zn}(2+)$-binding site on S100B as determined by NMR spectroscopy and site-directed mutagenesis. Biochemistry 42:13410-13421. https://doi. org/10.1021/bi035334q

Wilder PT, Varney KM, Weiss MB, Gitti RK, Weber DJ (2005) Solution structure of zinc- and calcium-bound rat S100B as determined by nuclear magnetic resonance spectroscopy. Biochemistry 44:5690-5702. https://doi.org/10. 1021/bi0475830

Williams RJ (1960) Binding of zinc in carboxypeptidase. Nature 188:322. https://doi.org/10.1038/188322a0

Wilson M, Hogstrand C, Maret W (2012) Picomolar concentrations of free zinc(II) ions regulate receptor protein-tyrosine phosphatase beta activity. J Biol Chem 287:93229326. https://doi.org/10.1074/jbc.C111.320796

Wong SH, Francis N, Chahal H, Raza K, Salmon M, ScheelToellner D, Lord JM (2009) Lactoferrin is a survival factor for neutrophils in rheumatoid synovial fluid. Rheumatology (Oxford) 48:39-44. https://doi.org/10.1093/rheum atology/ken412

Xia N, Liu L, Yi X, Wang J (2009) Studies of interaction of tumor suppressor p53 with apo-MT using surface plasmon resonance. Anal Bioanal Chem 395:2569-2575. https://doi.org/10.1007/s00216-009-3174-1

Yamasaki S et al (2007) Zinc is a novel intracellular second messenger. J Cell Biol 177:637-645. https://doi.org/10. 1083/jcb.200702081

Yang Y, Liu C, Lin YL, Li F (2013) Structural insights into central hypertension regulation by human aminopeptidase A. J Biol Chem 288:25638-25645. https://doi.org/ 10.1074/jbc.M113.494955

Yu X et al (2014) Small molecule restoration of wildtype structure and function of mutant p53 using a novel zinc-metallochaperone based mechanism. Oncotarget 5:8879-8892. https://doi.org/10.18632/oncotarget.2432

Yu B, Tang Y, Cai D (2020) Brain is an endocrine organ through secretion and nuclear transfer of parathymosin.
Life Sci Alliance. https://doi.org/10.26508/lsa.20200 0917

Yui S, Nakatani Y, Hunter MJ, Chazin WJ, Yamazaki M (2002) Implication of extracellular zinc exclusion by recombinant human calprotectin (MRP8 and MRP14) from target cells in its apoptosis-inducing activity. Mediat Inflamm 11:165-172. https://doi.org/10.1080/096229350201382 08

Zackular JP, Chazin WJ, Skaar EP (2015) Nutritional immunity: S100 proteins at the host-pathogen interface. J Biol Chem 290:18991-18998. https://doi.org/10.1074/jbc. R115.645085

Zackular JP et al (2016) Dietary zinc alters the microbiota and decreases resistance to Clostridium difficile infection. Nat Med 22:1330-1334. https://doi.org/10.1038/nm. 4174

Zaitseva I, Zaitsev V, Card G, Moshkov K, Bax B, Ralph A, Lindley P (1996) The X-ray structure of human serum ceruloplasmin at $3.1 \AA$ : nature of the copper centres. JBIC J Biol Inorg Chem 1:15-23. https://doi.org/10. 1007/s007750050018

Zalewska M, Trefon J, Milnerowicz H (2014) The role of metallothionein interactions with other proteins. Proteomics 14:1343-1356. https://doi.org/10.1002/pmic.201300496

Zastrow ML, Pecoraro VL (2014) Designing hydrolytic zinc metalloenzymes. Biochemistry 53:957-978. https://doi. org/10.1021/bi4016617

Zeng J, Heuchel R, Schaffner W, Kagi JH (1991a) Thionein (apometallothionein) can modulate DNA binding and transcription activation by zinc finger containing factor Sp1. FEBS Lett 279:310-312. https://doi.org/10.1016/ 0014-5793(91)80175-3

Zeng J, Vallee BL, Kagi JH (1991b) Zinc transfer from transcription factor IIIA fingers to thionein clusters. Proc Natl Acad Sci USA 88:9984-9988. https://doi.org/10. 1073/pnas.88.22.9984

Zitka O, Krizkova S, Huska D, Adam V, Hubalek J, Eckschlager T, Kizek R (2011) Chip gel electrophoresis as a tool for study of matrix metalloproteinase 9 interaction with metallothionein. Electrophoresis 32:857-860. https://doi.org/10.1002/elps.201000526

Publisher's Note Springer Nature remains neutral with regard to jurisdictional claims in published maps and institutional affiliations. 